University of Louisville

ThinkIR: The University of Louisville's Institutional Repository

Electronic Theses and Dissertations

1943

\title{
Effect of infrared radiation upon an oleoresinous enamel : compregnation of wood testing of dimethylolurea plastic
}

James I. Stevens 1920-2010

University of Louisville

Follow this and additional works at: https://ir.library.louisville.edu/etd

Part of the Chemical Engineering Commons

\section{Recommended Citation}

Stevens, James I. 1920-2010, "Effect of infrared radiation upon an oleoresinous enamel : compregnation of wood testing of dimethylolurea plastic" (1943). Electronic Theses and Dissertations. Paper 2174.

https://doi.org/10.18297/etd/2174

This Master's Thesis is brought to you for free and open access by ThinkIR: The University of Louisville's Institutional Repository. It has been accepted for inclusion in Electronic Theses and Dissertations by an authorized administrator of ThinkIR: The University of Louisville's Institutional Repository. This title appears here courtesy of the author, who has retained all other copyrights. For more information, please contact thinkir@louisville.edu. 
UNIVERSITY of LOUISVILL

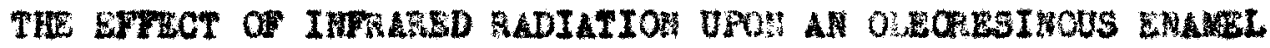
cottheakrion of wood

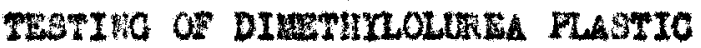

\author{
A Thealo \\ Subaltted to the Paoulty \\ of the Gradue te School \\ of the Univerutty of Loularille \\ In Partial Fulfilinont \\ of the Requirewents \\ for the Degree of \\ MASTER OF CHEUICAL EETWARINO
}

Departaent of Chemieal Eng Ineerins

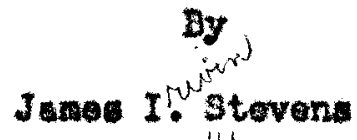

1943 


\section{UNIVERSITY}

LIBRARIES

This PDF document is a scanned copy of a paper manuscript housed in the University of Louisville (UofL) Libraries. The quality of this reproduction is greatly dependent upon the condition of the original paper copy. Indistinct print and poor quality illustrations are a direct reflection of the quality of materials that are available for scanning. The UofL Libraries greatly appreciates any better copies that can be made available for replacement scans. 
(1) THE EPFECT OF INFRARED RADIATION UFON AN OLBOABSINOUS BMAUEL

(2) COUPREGMTION OF

TESTIWC OR DIMETHRLOLUREA PLASTIC

James I. Sterens

Approved by the Examining Comittee:

Director (1) $\frac{\text { R. C. Ernst }}{\text { Director (2) }}$

May 14,1943 


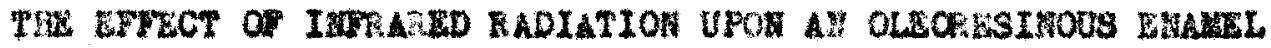

Page

1. Liat of Tables $\ldots \ldots \ldots \ldots \ldots \ldots \ldots \ldots \ldots \ldots \ldots \ldots \ldots$ I

2. List of P1gured $\ldots \ldots \ldots \ldots \ldots \ldots \ldots \ldots \ldots \ldots \ldots \ldots \ldots \ldots \ldots 11-111$

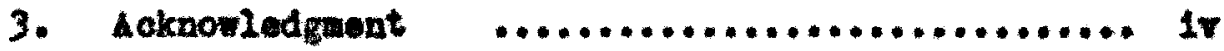

4. Abatract $\quad \ldots \ldots \ldots \ldots \ldots \ldots \ldots \ldots \ldots \ldots \ldots \ldots \ldots . . \ldots$

5. Introduction $\ldots \ldots \ldots \ldots \ldots \ldots \ldots \ldots \ldots \ldots \ldots \ldots \ldots$

6. Mlstorical $\ldots \ldots \ldots \ldots \ldots \ldots \ldots \ldots \ldots \ldots \ldots \ldots \ldots$

7. Theorotical $\ldots \ldots \ldots \ldots \ldots \ldots \ldots \ldots \ldots \ldots \ldots \ldots \ldots$

8. Experimentml $\ldots \ldots \ldots \ldots \ldots \ldots \ldots \ldots \ldots \ldots \ldots \ldots \ldots 12$

flaw Haterials $\ldots \ldots \ldots \ldots \ldots \ldots \ldots \ldots \ldots \ldots \ldots \ldots \ldots$

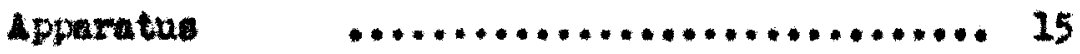

Procedure $\quad$............................ 19

9. fievult $\quad \ldots \ldots \ldots \ldots \ldots \ldots \ldots \ldots \ldots \ldots \ldots \ldots . \ldots \ldots$

10. Conolumions $\ldots \ldots \ldots \ldots \ldots \ldots \ldots \ldots \ldots \ldots \ldots \ldots . \ldots 4$

11. Literature cited ......................... 50

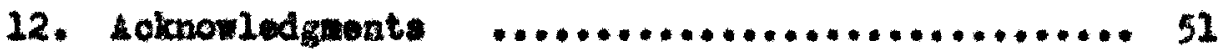


COMAscampron of no00

1. Wet of Tables

2. Liat of Figures

3. Acknow Lediment

4. Abotract

5. Introduetion

6. Hetorioal

7. Theoret1on

B. Experimental

Apparatus

new Material

Procedure

9. Tesult and interpretatione

10. Conclusions

11. isterature C1ted

TESTINO OF DIUETEYLOLIFA FLASIC

1. List of Tebles

2. Wist of Pigures

3. Introduction

4. ixperimental

5. Fenits and Conclusione

6. Acknowledgente

7. V1ta 
II Phy lan Propertlee of Enmel Formulatione at Varyling Ageo 
LIST OF FICURES

1.

Page

1 Volume percent Unextractable ve. Age for 16

Gellon LInseed 012-Bekell te Varnioh with onehalf the Fesin roplaced by Titeniun Dloxide

2 Porcent slongstion vs. Paroent Neflectence of

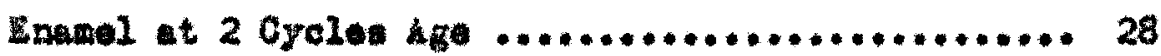

3 Porcent Elongetion va. Percent Refloctance of Enamel at 4 Cyoles Ag .......................... 28

4 Percent Elongation re. Parcent Imand at 6 Cyoles 4 ge ......................... 29

5 Porcent Elongation v*. Percent Reflectance of Enamel at 8 Cycles $4 \mathrm{ge} \ldots \ldots \ldots \ldots \ldots \ldots \ldots \ldots \ldots \ldots \ldots \ldots . \ldots 29$

6 Percent Elongation vo. Percent Reflectance of Enamel at 10 Cycles Age ...................... 30

7 Percent Elongation va. Age In Cyoles of Enemel at 61 Parcent Rerlectance .................... 30

8 Percent Elongetion ve. Age In Croles of Enamel et 55 Peroent Fefloctance ..................... 31

9 Perout Blongetion va. Ag in Cyoles of Enamel

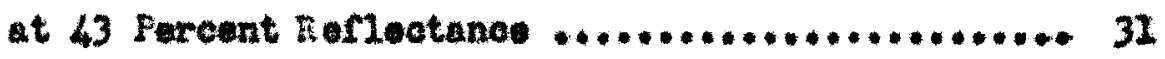

10 Porcent Elongation ve. Age in Gycles of Enamed at 27 Porcent Rafleotance .................... 32

21 Peroent Elongation v8. Age in Cycles of Enamel

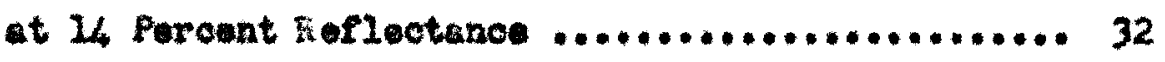


LIST of PIoters (continued)

Pigare

12 Volume Percent Unextraotable va. Age in Cycles of Inamel at 80 Peroent Kaflootance ................ 34

13 Volume Percent Unextraoteble vs. Age in Cycles of Enawal at 61 Percont fierlectance ............... 35

14. Volwme Percent Unextractable ve. Age in Cyeles of Enamel at 55 Fercent fionectance ................ 36

25 Volume Percent Unextractable va. he in Cyoles of Envel at 43 Percent neflectunce ............... 37

16 Voluse Fercent Unextracteble va. Age in Gycles of Tnamel at 27 Percent forloctance .............. 38

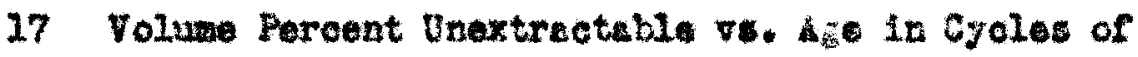
snamel at 14 parcent feflectance ................ 39

18 Volwe Parcent Unextractable vs. Pezcent Reflectance of trawel at O Cycles Ag............ 41

19 Volum Percent Dnextrectable $\mathbf{7 s . ~ P a r c e n t ~}$ Reflectance of Enamel at 2 Cycles Ate .......... 42

20 Volume Peroent Unextractablo ve. Percent

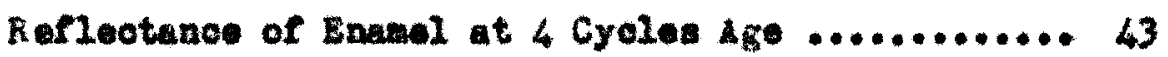

21 Volume Percent Unextractsble vi. Percent For Lectanoe of Enemel at 6 Cyoles hge ........... 44

22 Volume Percent Unextractable va. Percent Reflectanoe of Enamel t B Cyoles Azo .......... 45

23 Voluwe lercent Unextractable v8. Peroent Fenlectance of Enamel at 10 Gyoles Age ..........46 
ACHNowLDDotarm

The suthor wisher to acknowledge the

kind assietunce and helprul ulano

of Doctor F. C. Ernst, who

dirocta this reacarch. 
ABSTACT

The purpose of this investigation is to deternine the effect of Infrared rediation on the struoture of an olooresinous enamel wade of Lineod 011, Dakel1te, Fealn, and Itaniva Dioxide as the pigmant.

Enanels were propered by using varlons ratios of t1taniu dioxide and Lambleok os the plgents to give different degreas of infrared reflectence. The realting enamels were cast into flis: which wore weathered. The eged r11ne were then tested for distenablilty and flnily extracted ith scetono.

It we concluded that botween $40 \%$ and $60 \%$ ro Nlactance of the infrared aximu polymer content in obtained. It so postulated that tha way be cased by a combination of (1) a retardation of oxidation by the pizment. used, (2) breakinf down of polymers already formed, or (3) the fallure of a filu to recolve enough radiation of apectelo type to cause maximum polymer formation. 
Im oovorrot 
This invatigation has for 1 to purpose to determine the effect of infrarad radation on the polyserization of ponted oleoresinous varniahes. Lingeod oll - Bakell to type varniah, plecented wh thanfun doxide and lampblack 111 be atudied.

The oharacter of oleoreatnous 1 las has been under Inveatligation by Ernot and other: $(3,4,5)$ for sevaral years In this laborstory. The previous investigstlons have eatab11shed that by the use of an acotone extrection an oleoreatnous PII way be separated into two conat1tuentst 'polynar' and 'non-polymer'. The polywers are made up of three dimenutonal polywerle (polywer) substanees which serve to forw the Plin and are acetone insoluble. The non-polyweriaed or slightly polyuorized wateriel (non-polywer) are acetone soluble and form the plastiolzer portion of the flim. These Invostigation have been concerned with this polymer to non-polywar ratio in conmection with the age of the filn.

The prowlous invastlgator found that during the

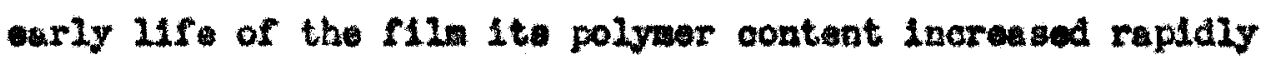
bat later increased less repidiy until finally conatant walue was epprosched as the film neared fallure. It was alwo found from the Inveatigation of enasele that with the pigments inveotigated they affocted the rete of polymorigation only to a 
ollgbt extent. The polywer content at fullure when the resin-plganat ret10 wh les than 1-1 depended upon the piznent, the dryinf o1l, and the oll length. When ifty percent of the reain is replaced by plgment in varnishes of the insoluble type realns (Bakelite) the substitution say bo sade without offootively ahang ing the polywer content at fallure. In the aoluble type realns (fister Guil) only Inert plgmente woh as titenlue dioxide vay be oubstituted ithout increasing the polymor contont at fallure.

It 1. the purpose of this Inveatigstion to determine how radiation in the red and infrared of the spectram will affect the rate of polynseriation and the 11f of the film. It is hoped that this investigation -111 further ald in the formilation of attiafuotory fin1mben. 
Mstorical. 
It t. a wl know fact that light of varlous wave lengthe has alfreront arfects upon ofl and palnt f11ms. Conalderable work $(23,14,15)$ has bean dow in rogard to the effeot of witra-violet 11ght upon olla and paint r2lan.

The effeot of light of longur wre lengthe (above 7000 i) bes reoelved litile atteition la regard

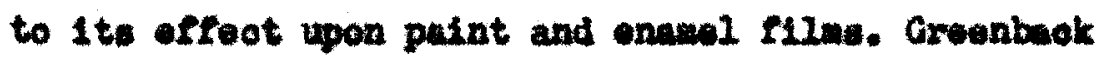
and Holn (1) atate that samples of cottonseed oll. butter 011, com 011, and Iard aboorb approximately the amo anount, about 5 porout, of 4 ght between $5400 \AA$ and 7500 i. They also 1ndioate that the peroent of 14 ght ebeorbod Inaxweos with deorenae in wave Lensth.

Cangull (6) akows by numarous exanples that Infrured radiation is effoctive in only fou cases In beinging about the rapture of noleoules. His treatment 1s largely athomation and deals with unimolecular reeotion.

Considarable work, an previously roported $(3,4,5)$ has been done on the change of polywer oontent In the aring of filns. The initlal investigation in these laboratorles was conduoted by Ernst and MoGulikin

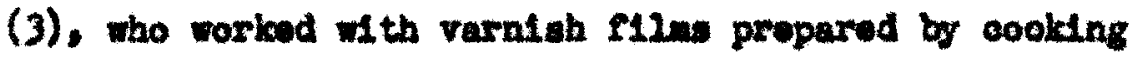

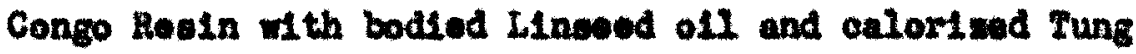
011. 
Varlous ofl langths were unod, and the enamels were propared by grinding titanlum dloxide in these varnishes. The ahange In polynar content and the distansibility change were otudfed throughout the Iffo of the F1Im. Irnat and Mopuiztein obeerved that the oonoentration of polymor, as Indicated soetone extraction, reached a value of fros $70 \%$ to $80 \%$ at fallure of the fila, we Indieated by aintwu distensibility. Irom these obeorvations they oonoluded that during the 2ife of an oleorealnous fill complicated notwork of three-dimenolonal oll and restn nolecules is forwed which gredually deartasos the elestiolty of the f110 unt1l fallure ocours.

Ernat and Lubber: (4) oxtended thle fundamental rosoaroh so that it included varnishon formulated from typtosl drying o1ls and aeveral oyntbotio reains. The

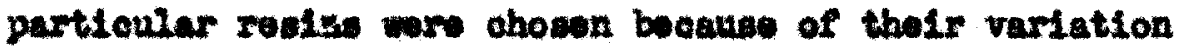
In renotivity and chenloal type. From thoir obearvationa, uelng the same experimental wothods and wodes of correl-

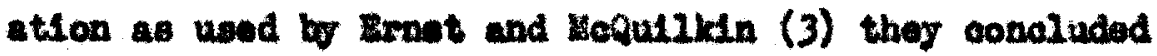
that the varniahes oould be divlded into two olaseses acoording to the reain contalnod. The firat oleas contained realns of the "Insoluble" type and tonded to promote polymerlsation, the encond olase wae composed of the "solublo" type rosins and tondod to rotard polymor- 
1zation. The type "solublo" or "Insoluble" la reforred to thoir wolubill ty in soptone.

In continuing the Inwastigation, Frnst and Budaley (5) workad with onumels in which thoy varled oll leagth, type of all, type of reatn, and tope and amount of plgment. They concluded, firot, that the plgmentw investtgated affeotod the rate of polywerl sation only allghtly; sooond, that the polymor osntent at fallure -1 ther inereased or decreased doponding apon the resto, pigment, and o12; third, the magaltude of this variation that ooours is dopendent upon the drying ofl and the oil longth wen plgment is aubetituted for the resin in amounte low than fifty percont, and fourth, whore fifty porcent of the rosin is repleced by pigmont, subotitution can bo made in ineoluble type reains with offeotivoly no obange; but in woluble type realos only langts, like titanilu diaxide, nay be subetstuted it thout effoet. 
THEOERTCAL 
Thla Inventigation does not propose to collect additional data whioh w11 furthor insight into tho mochantan of drylng of olooresinous filns but attempts to explain the change in fulm when exposed to light of long wave length. When oorrolated with provlous work, the datio obtained in this Invostigation should be of value in formulating protootive coatinge. The mochanten of the 'drying' reaction of a drying oll is gonorally considared to be oomblnation of oxygen abmorption and noloevlar assoolation or polymorisution. Although the formation of a film is dopendent upon ox yoen aboorption, the PLIm does not Imediately absorb oxygen but goes through an induction perlod the length, of which is goverened by treces of antioxidante in the oll. The addition of motallio drlera appreolubly abortens thie inlelel indnotion parlod. Host Investigators $(10,11,12)$ conulder this oxrgon absorption to form peroxide Iinkages at the double bonds.

Thore are many controveralal date and opinione concerning the exnet nature of the laterlinicting to form polymors. The firet is the combination of unsaturated noleoulos by primary chouloal IInkuges to form larger molecules, true polymorization. The woond type of 
polynerisation is that in which combination of unsaturated compounds take plece through secondary or resldund relenoles. Thle type of polywariantion is alled collotial asaodation.

Powart, Overholt, and EIn (2) 11st five stops wo diacernible in the orylng and aglng of a fling 1) a perlod of induetion before oxidation le appreatables 2) period of most repid oxldation; 3) oxygon apparontiy rearmanges, forming oonfugated oyatem if they are not already present; 4) polymerisation socompanied by a rapid

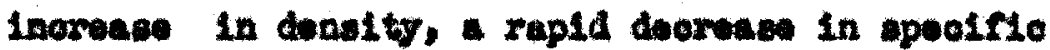
refrection, and a rapld drop in lodin values and 5) the agting step ocourring ware lowly and chametarlad by depolymerisetion or oxtdativ decompostition of the polyoers previonaly formed.

Rhodes and Coldankth (9) state that Lampleak and Carbon black markedly Inhibit the oxtdation of

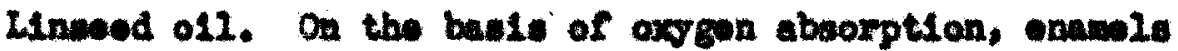
containing olther of these plgments showld oontain 1 es

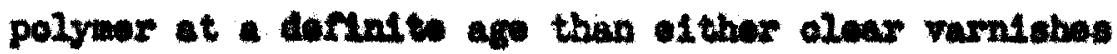
or other enamele in a Inseed oll rahtole. In tholr exportente, however, they uned large ratio of pignont to ol1. 1.e., one part of plemont to mins parts of oll by welgt.

Invostigation by Oreonback and Holn (1) point 
to the ract that the porount absorption of $11 \mathrm{ght}$ and the poroxtds formation lnorvases with doereasing wro length of the 14ght. Ganduld (6) postulates that 1 is posatbie for infrared radiation to rupture a for types of noleoules. On the bests of these date it is Indicatad that the polymers would be alom to form and after formation ay bo brokon elther by the cotion of the infrared of the depolyweriention or oxdintive docomponttion during tho aging poriot.

The previous inveotigation: $(3,4,5$,$) hare$ reveuled that the peroent elongation of a flie when freahly prepared is larg and the polyner content is 10w, but that it deoreasea and approachos a mintau value ws the polyoer content reaches ite conatant velus. This dimlalahing diotenosbility it a woagaro of 112 fallure. 
ERER IUEMTAL 


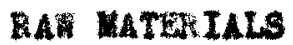

A 16 gellon Lineed 011 - Bakellte varal sh was uaed in thio inveatlgation. The drying o11 used was a $2-3$ bodied Linsead oll.

The plgents traed war C.F. TItanium Dioxide and Lamplack. Fure titantum doxide wes ground in the oll to form paste and cocond pate wa wade by grinding titumIu dloxide and andl percentage of lamblack with the 011. The ratio of oil to plgent wa such that in making the enanele it was neceasary only to weigh out a calculated ancunt of the verniah and the pastes. The varnish and patos, together with the thinner and drier, were thoroughly Ixed to secure a howogeneous enamel.

Xylene ves uaed to thin the enamels to epproxiantely the same peroentage solids as the original varnish. Drier wes added to the formiation in the form of rogular Wrodex leed, manganese, and oobelt drier, containing 24,6 , and 6 percent metal, reapectively. They were odded to the enavel formlations on tsetal to 011-added weight basia of $0.30 \%$ 1eat, $0.03 \%$ manganese, and $0.015 \%$ cobalt.

The plament was added on the beats of replacing one half of the resin with pigment. This was to insure good hiding end to duplicate the type of emanel found to be most satiafactory for this investigation after close examination 
of the data of Kirnat and Eudeley.

Whon exposed to uitra-violet 11gtht, this enamel

gave only a polymer change during the efing cycles. The 12ght wource used omitted benda of ultramiolet in addition to red and infrared, the effect of the ultraviolet would be minialzed by the use of the Linseed oflSakalit varnich plesented th titanium dioxide. 
APPAHATUS

The pparatue used in this inveatigetion consioted chlerly of an acoelorated weathering untt, a distenolbility tester, a bettery of axtraction units, and antirarpose reflectomoter. Other equ1prent inoluded palat w11, a f1lm caster, a dial cuse ncrobeter, and conatant-tenperature, oonatantmbumidity oubinet. 412 this equipment is described In the rollowing peragraphs.

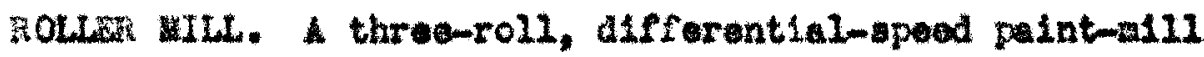
was used to disporse the pigent in oil. Several passes tore ade to inaure complete dispersion. VIL CAstert. The filws for this Investigation were cast by means of a doctor blade having a clearance of 0.006 inchen. The caster hes an overall lath of 4 is lahes and deposits filne 3 incher wide.

PAKELS. 411 112u were cast on 31 gange coke tin panels $5 \times 10$ Inohes in size, having $t$ Inoh holes centered inch from the top.

ACCELEXATED WATHE IWO UWIT. Fapld weathering was brought

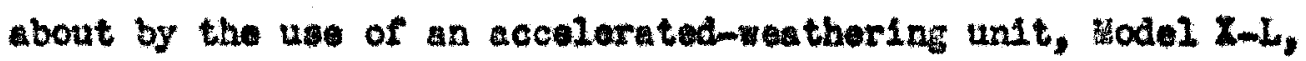
manufactured by the thenal Carbon Company. The unit is in the forn of cylinirical, copper-costed, vertical steol ahell, contelning rotating panel reck. Thls rack has oarrying 
onpacity of 64 panols and rotates 360 degroes every 118 Inutes. Sadiation was produced by the use of "Metional" B Carbons which have high emiaston value in the red and infrared. (17)

COHSTAM-TEMPERATUE, COASTANT-HUMDITY CABINET, An Insulated box mintained at $70^{\circ} \mathrm{F}$, and 546 relative humidity served a constant-temperature, constant-bumidity cubinet. The tumperature was intalned by thermontaticaily operated Inoandoscent lamp heater. Inumidity was controlied by the use of aturated sointion of agnestua nitrate hexam hydrate, in an opan pan as sugested by Gardner (7). Such a solution, when contalina in a compartment wo wa the and at $70^{\circ} \mathrm{F} .$, will bold the atmosphere of the enclosure at 546 relative bumidity.

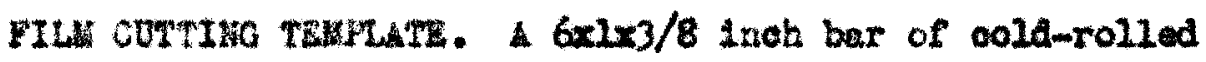
steel was poliobed on one $2 \times 6$ inch face sad used as tamplate for cutting the strips of f1la used in the olongation testa.

MIOR ONETER. The thiokness of the froe enemel filme wes weasured with a Randull Stickney disl gauge nioromotor. The dial is graduated in thousand the of an inch and readings oun be Interpolated to ten-thousand the of an inch. ExTiacrion UnITs. Aftor aging and elongating the rilna vere extractad in Sohxlet extraction unite. Uaoh undt consiatod 
of $400 \mathrm{mi}$. extraction flesk, a siphon oup, en extraction thimble, and condenser cap. The stphon cup containing the extration thimblo with the fIIm was suapended by fine wres from the condenes oap which rested on the neak of the flask. The unite wore contained in five batteries of twelve unfte each. The betteries ware in the for of rectangular wooden boxes lined with asbestos paper, and fitted with removable lids in whioh holes wore cut to recolve the extraction rlasks. The rlsake were placed in cylindrical metal reflectors which drected the hert to them from the 75 wett Incandetcent 2 amp heaters. Cooling water for the condensers wes oupplled through an fron plpo manfold and the cooline systom of the battartos were connected In aerles. FerLECTOWETh. A Hunter (16) multipurpose roflectometer was used to deterzine the percentege of infrared reflection. A. Wratton 87 filtor was used. The 1nstrument was standardized for this filter by use of porcelain stendard which had a reflectunce of 81.9 percent when compared with Hagneniug oxide, which has a reflectance of 100.0 percent. DISTEMSIRILITY TESTEF. The diutensibility tester used wae manufactured by Testing tachines Inc. This actine is equipped to record autometically the elongation and losd 
under which film falled. The rate of pall is 4 inches por ainute, maxima elongation is 27 mat, and maximan load obtainable is 10 kilogram. 


\section{ProcsDor:}

The procedure consisted of preparing the ensuel, cating the f12u on panels, aging, and determining the reflectance values at varlous ages. The panels were then asalgemated and the filo tripped cree. The fros flins were conaltioned, longated, and extreoted. An explanation of each step rollowe.

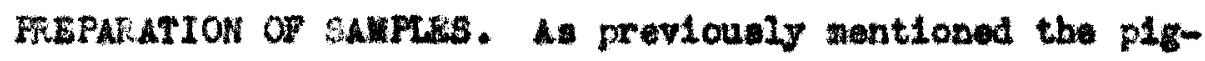
wants were round in 011 so that defint to ratio existed betwesn pigent and oll. It was necesenry only to welgh out the varnith and add a defintte weight of pates, driers, and thinner. This was then agltated to obtaln homogeneous atxture. The amples are ohecked for thorough dispermion of the lanplack by the uae of a morosope. CASTIKC on FIuks. Flate glase panels wero leveled, a few arops of ater spread on their surface, and the tin panels, thoroughy cleaned with $x$ lene, were firmly preseed onto the retted lase arface. It io neceseary to obtala good

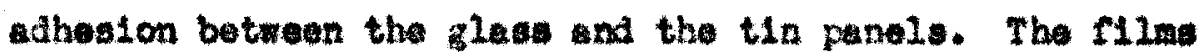
vere then cas ith the dootor blade uaing a conatant forward pall of 1-2 Inchea per sooond. All unples were cat in dupl1arte.

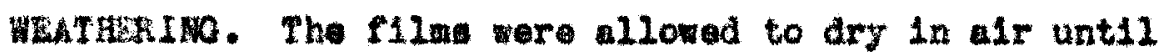
they were taok frea. The panela wore then trimad to $3 \frac{1}{8}$ by 10 inebes and pleced in the accelersted weathering unit. 
They were exposed to the action of infrared 14 ght and water for period of $2,4,6,8$, and 10 cycles. A cyclo was tuken a 12 hours of I1ght and water. This differm from the previously used oyole In that there is no period of solely 11ght or water. No reat or refrigeration period 1a used. This cycle was chosen becaue it closely approximated all forernwent peclelcutions as to the conditions of socelerated weathering. The panel were taken from the unit at the end of each even cycle, Inepected, and their percent reflectunce deterined.

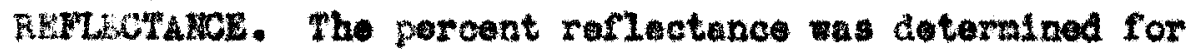
onoh Clia the end of ewch even rumbered oycle. The Hunter rellectometer is so construoted that a panel 111 f1t convenlently over the aperture for the maple. The wabine wa standardized affalnat tho porcelain otandard at tho beginning of each set of deterainations and the value checked after raking the roudinge.

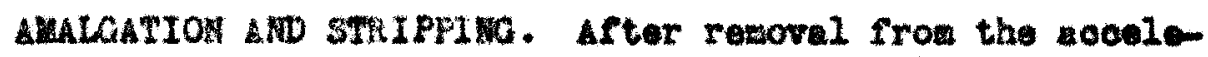
rated weathering unit, the panols wore incilned t an angle of approximately twenty degrees wib the horizontal and a arop of mercury placed on the unproteoted notal murface above the top adge of the f12. After remining in the poultion overnight the tin surface was completely andgated. This 
urface is woh that there is only a anall degree of adherence with the flim so that it is posaible to lift one ond of the IIIm with the analatance of a razor blede and utrip the f1Im from the panel. CONDIrIONIma. The free film ware bung in a conatantteaperature, constant-bunidity cubinot for at lesut three dayn; at the ond of thin time the filmo pere considered to reach tesporature-humldity equilibrium with the atmosphere of the cablnet.

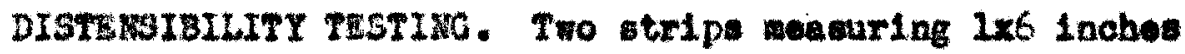
were cut from each condtioned f1Im. The strip ware cut with razor blade, using ateal teaplate as a pattern. The thlekness of exch f:Im was dotermined by averaging sovers l reatings teken with a dial gange miorometer. Tho auple strlpe were then cleaped to the Tasting Habine so that the sample length was 100 ans The cluteb of the mechine was then ongaged and sorew relensod so that the twachine would record the amount of longation. The percent - longation and lond were read directly i'roci the st tuchos soule. ExTisction. The polywer contont of the films was determined by extracting with sootone to conatant woight and conaldering the insoluble as polymer. A double thickness of 130 whatwan 
filter papor folded Into doublo thicknose, thataen extraction tisible. Ths thimble was then oxtracted with acetone for two days to perwit it to rouch constent walght. It wes then dried at $105^{\circ} \mathrm{C}$ for two hours, cooled in a dessictor, and wolghed. The wolghings were pertoraed in

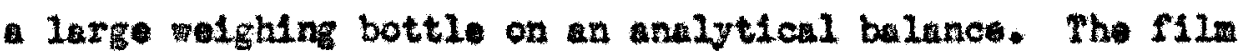
anple was cut into amall bits and placod in tho thimble. The thimblo was again dried, cooled, aad walghed, tho weight of the sample being deterwined by difference. The thimble, contalaing the ample, we then plaoed in an extraotion unit and extracted for approxiataly two weake to constant wolght. In woty thimblo was extracted wth oach ton anples a a blank to wininize any orror realting from olight changes in the weight of the thiable. The lose in weight of the sample was obta1ned by difference and the parcont of inaoluble meterlal remining was caloulatod. 
HEsurn: 
The forwulationa, abom in rable 1 , were onst Into P1Ina, aged, and the longation, tansLle atrongth and woxtraotable determined at various ages. It wes imposelble to obtain carbons for tho watboring unit whioh had an onteston opeotra high in the rod and infrared athout conalderable radiation in the volot and witramviolet. To mininise the efreat of the shorter wave lengthe of

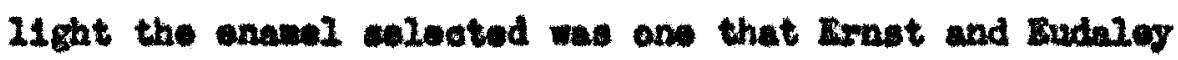

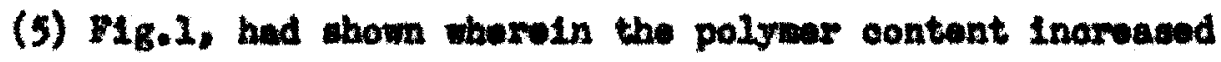
rery alowly whon expoeed to altra-riolst radiation. This - wamel we ade rrow 16 fullon LInseed oll-Babels te rarnith with $1 / 2$ of the resin repluoed with tituniun disoxids.

The roulte shom in Table 11 were based on the deternination of these experimental values at the ond of $2,4,6,8$, and 10 oyoles as wall as for unaged 11 ma. The peroentage refleotanoe $1 \mathrm{~s}$ the average of the values obtalned at the ond of each eron oyole during the agding of the sil. The roflectanos varied alighty during the aging prooces but nover over 38 from the average. The readinga fron the Hunter follectemetar when oorrooted by conalting the correotion ourve for the instrument give the poroentage refleotanoe of the flin whon magnesiu oxide is taken as 100 pereent refleotanoe of the infrared. 
TABL 2

Formaletions

cods

Poreantare of Planent.

Lamplack ritantu dio.

2u2-5-1

xแอน-5-2

TL1-5-3

2war-5mb

Tum $-5-5$

2xn1-5-6
0.00

100.00

99.95

99.50

99.75

99.25

97.59
Approx.

Perownt Infrared Rerleotanoo

81.6

63.0

55.5

43.5

27.5

4.8

TLB1-5, refors to L Lnsed oLI -Baladite varniah,

16 gellon oLl Iength, with one half of the reain repleoed ot th plenent. 
TABLS 11

Physten Proporties of Enamel Yormulationa at Varying hgos

\begin{tabular}{|c|c|}
\hline Serple & Phystad Propart \\
\hline$T B 1-5-1$ & $\begin{array}{l}\text { \& Beneetanco } \\
\$ \text { Dlongation } \\
\text { \& Unoxtractable }\end{array}$ \\
\hline$T \omega M 1-5-2$ & $\begin{array}{l}\text { I Reflectano } \\
\text { Ilongation } \\
\& \text { Jnoxtractable }\end{array}$ \\
\hline$T L B 2-5-3$ & $\begin{array}{l}\text { \$ Reniectance } \\
\text { \& Elongetion } \\
\text { Inaxtractabie }\end{array}$ \\
\hline $2181-5-4$ & $\begin{array}{l}\text { \$ Reneotanos } \\
\$ \text { Elongation } \\
\text { t Dnextrectable }\end{array}$ \\
\hline TLEL $-5-5$ & $\begin{array}{l}\text { \$ Denectance } \\
\text { \$ Dlongatien } \\
\text { \% Unextractable }\end{array}$ \\
\hline $2 L B I-5-6$ & $\begin{array}{l}\text { \& Eefleotanos } \\
\text { \& Elongation } \\
\text { \& Unextractable }\end{array}$ \\
\hline
\end{tabular}

\begin{tabular}{|c|c|c|c|c|c|}
\hline 0 & 2 & $\frac{48}{4}$ & $\frac{y c 10 s}{6}$ & 8 & 10 \\
\hline $\begin{array}{l}81.6 \\
51.9\end{array}$ & $\begin{array}{l}82.3 \\
-54.7\end{array}$ & $\begin{array}{c}80.8 \\
-0.6\end{array}$ & $\begin{array}{l}78.6 \\
\overline{67.4}\end{array}$ & $\begin{array}{l}79.5 \\
6.66 \\
69.9\end{array}$ & $\begin{array}{l}78.7 \\
6.66 \\
69.2\end{array}$ \\
\hline $\begin{array}{l}63.0 \\
60.5\end{array}$ & $\begin{array}{l}62.2 \\
27.4 \\
63.9\end{array}$ & $\begin{array}{r}61.5 \\
7.2 \\
70.3\end{array}$ & $\begin{array}{l}61.8 \\
8.75 \\
69.5\end{array}$ & $\begin{array}{r}61.0 \\
4.7 \\
6.5\end{array}$ & $\begin{array}{r}61.0 \\
4.9 \\
72.3\end{array}$ \\
\hline $\begin{array}{l}55.5 \\
58.4\end{array}$ & $\begin{array}{r}55.2 \\
5.4 \\
68.9\end{array}$ & $\begin{array}{r}55.0 \\
4.5 \\
67.3\end{array}$ & $\begin{array}{r}55.4 \\
5.4 \\
72.6\end{array}$ & $\begin{array}{r}54.8 \\
3.4 \\
75.0\end{array}$ & $\begin{array}{l}55 \\
48 \\
72\end{array}$ \\
\hline $\begin{array}{l}43.7 \\
61.9\end{array}$ & $\begin{array}{r}42.9 \\
7.7 \\
69.8\end{array}$ & $\begin{array}{l}42.9 \\
4.48 \\
70.1\end{array}$ & $\begin{array}{r}43.0 \\
4.0 \\
75.5\end{array}$ & $\begin{array}{l}42.9 \\
4.56 \\
74.5\end{array}$ & $\begin{array}{l}43.3 \\
4.27 \\
76.7\end{array}$ \\
\hline $\begin{array}{l}27.8 \\
58.7 \\
5.4\end{array}$ & $\begin{array}{r}27.6 \\
6.0 \\
69.8\end{array}$ & $\begin{array}{r}27.2 \\
2.7 \\
66.9\end{array}$ & $\begin{array}{c}27.3 \\
3.7 \\
70.00\end{array}$ & $\begin{array}{r}27.3 \\
3.5 \\
72.9\end{array}$ & $\begin{array}{r}27.4 \\
1.5 \\
70.2\end{array}$ \\
\hline $\begin{array}{l}13.8 \\
52.4 \\
52.6\end{array}$ & $\begin{array}{r}15.7 \\
2.0 \\
61.1\end{array}$ & $\begin{array}{r}4.9 \\
2.0 \\
64.8\end{array}$ & $\begin{array}{r}14.6 \\
1.8 \\
60.4\end{array}$ & $\begin{array}{r}14.2 \\
1.5 \\
65.0\end{array}$ & $\begin{array}{r}14.3 \\
1.5 \\
60.7\end{array}$ \\
\hline
\end{tabular}

*** - Too elastic to elongate

- - Differont testhing maohin uod. 


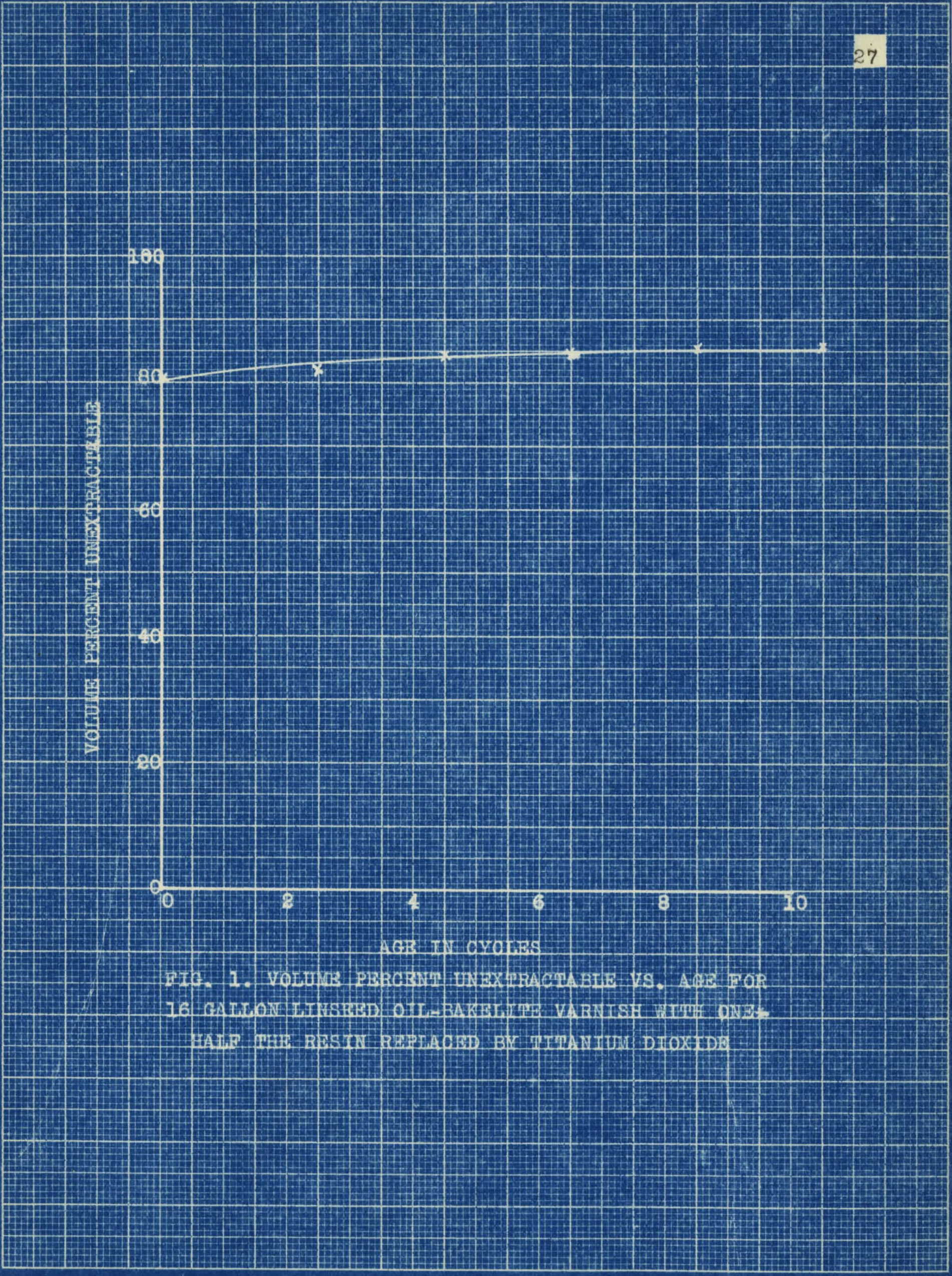




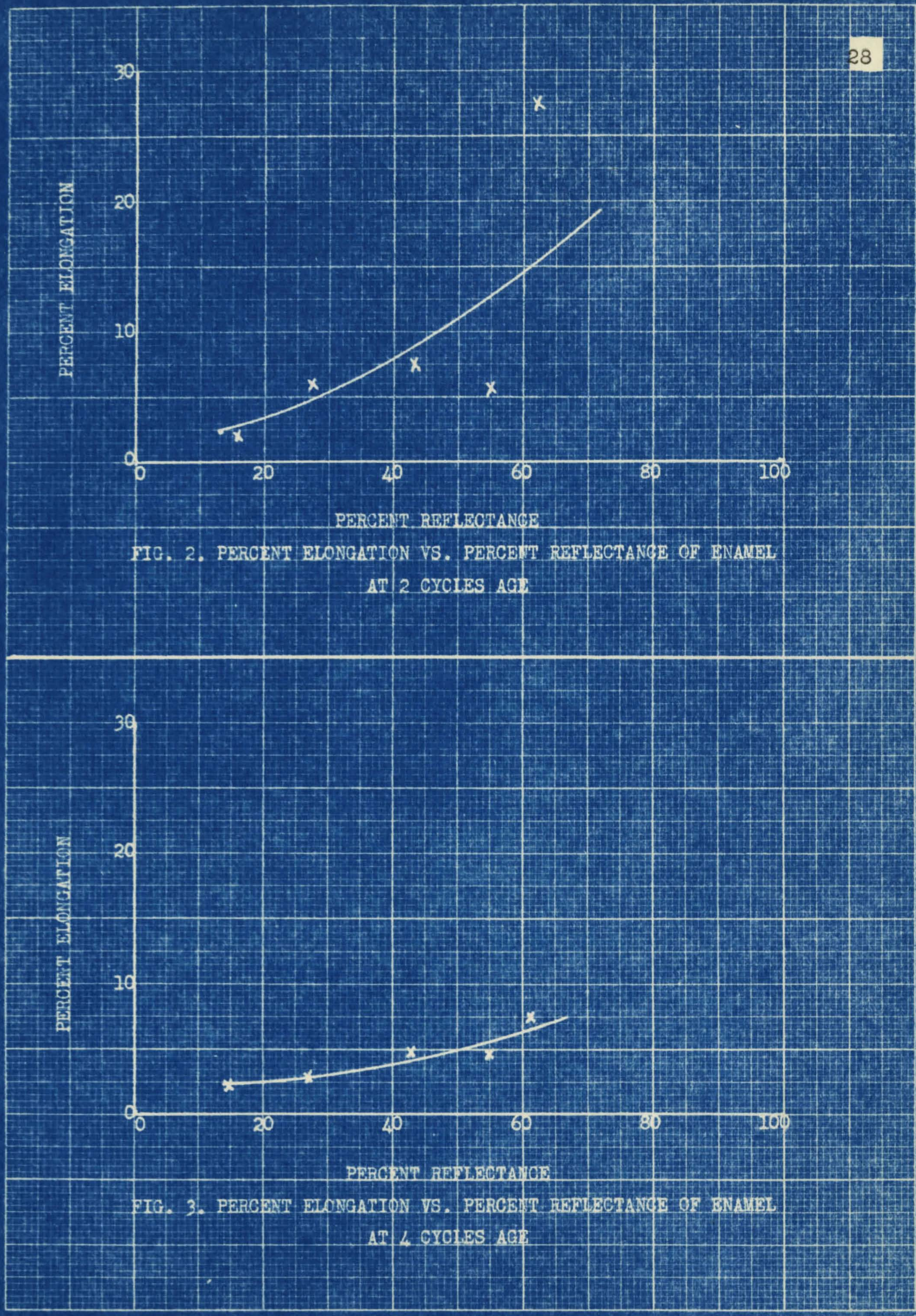




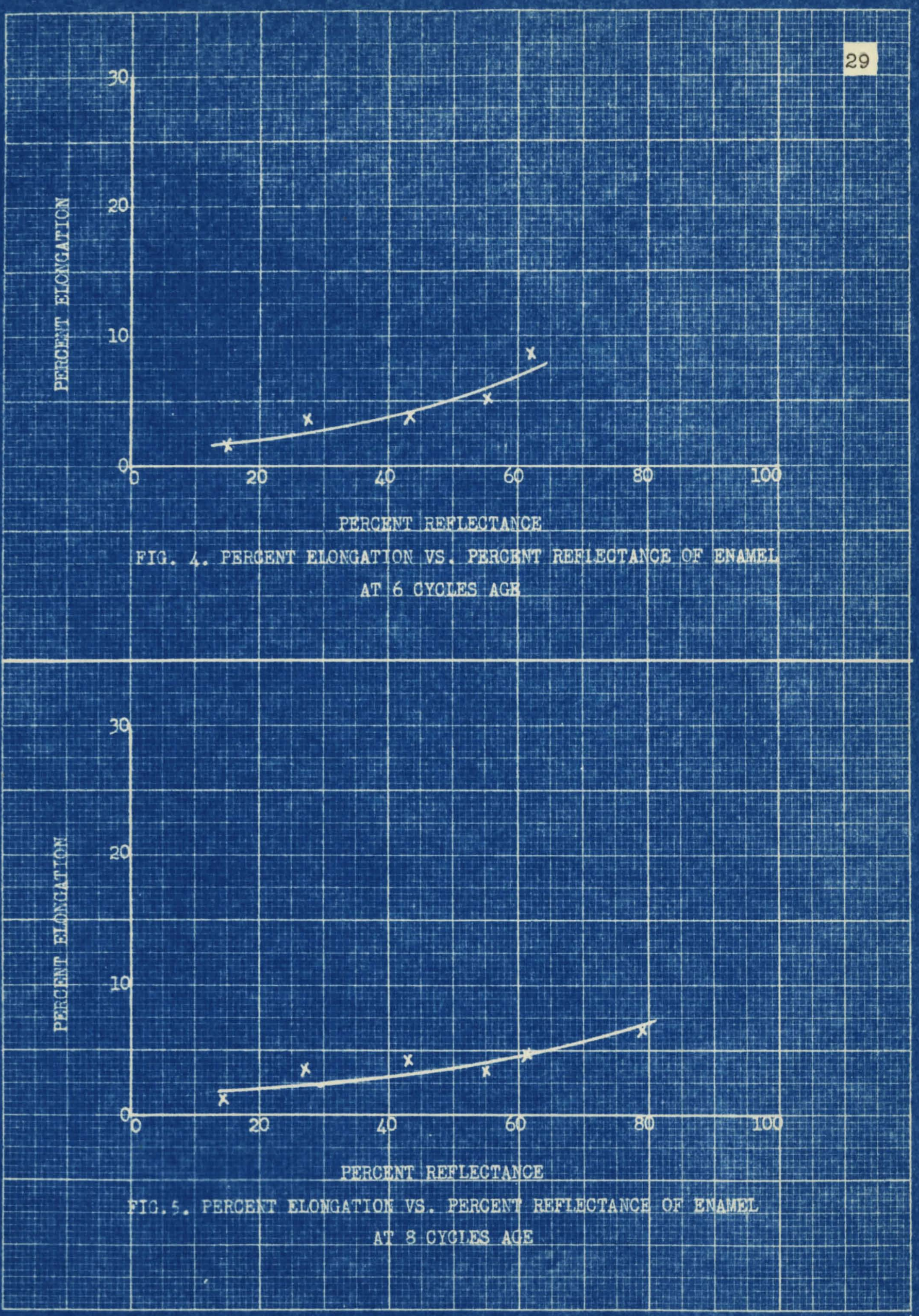




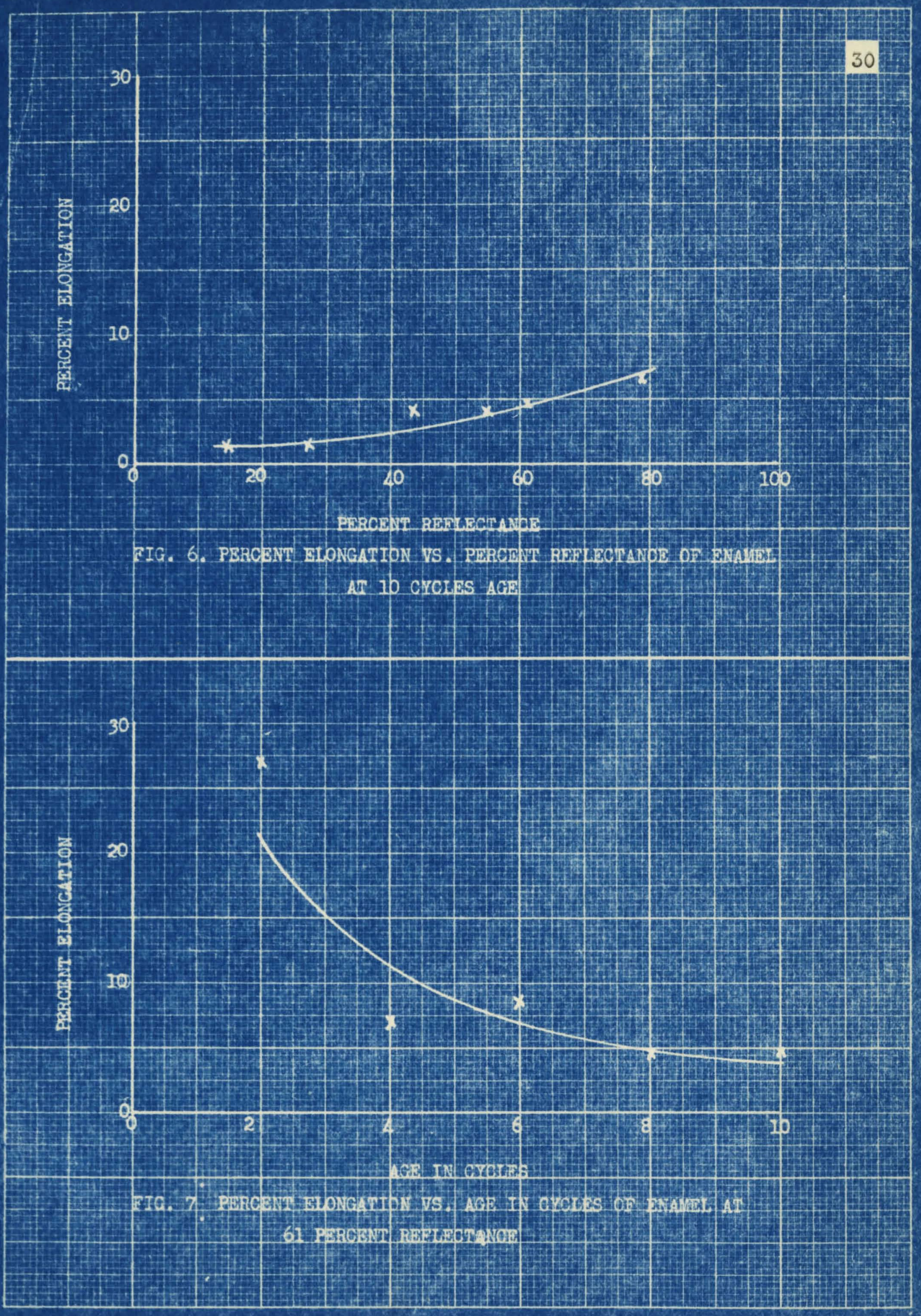




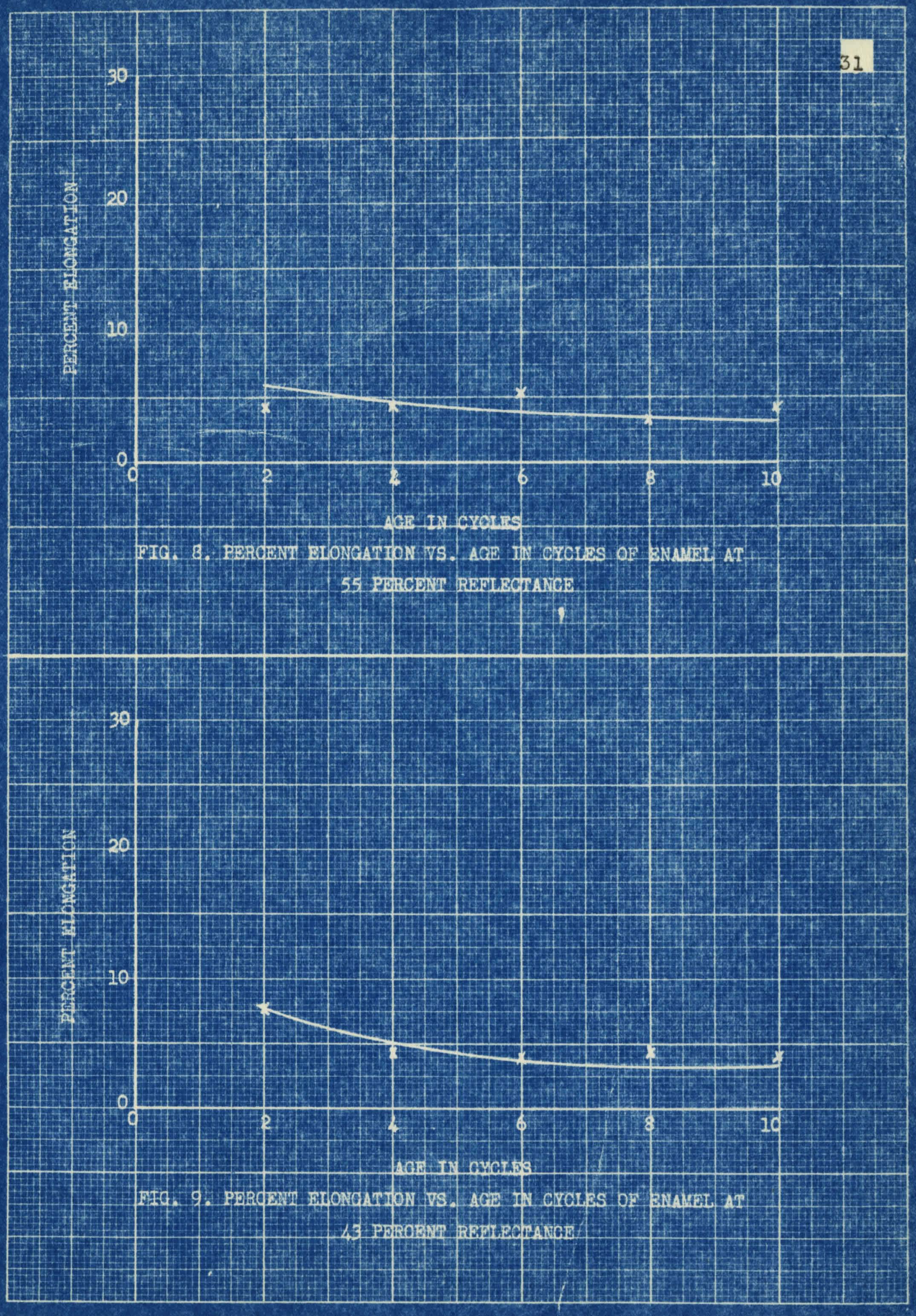




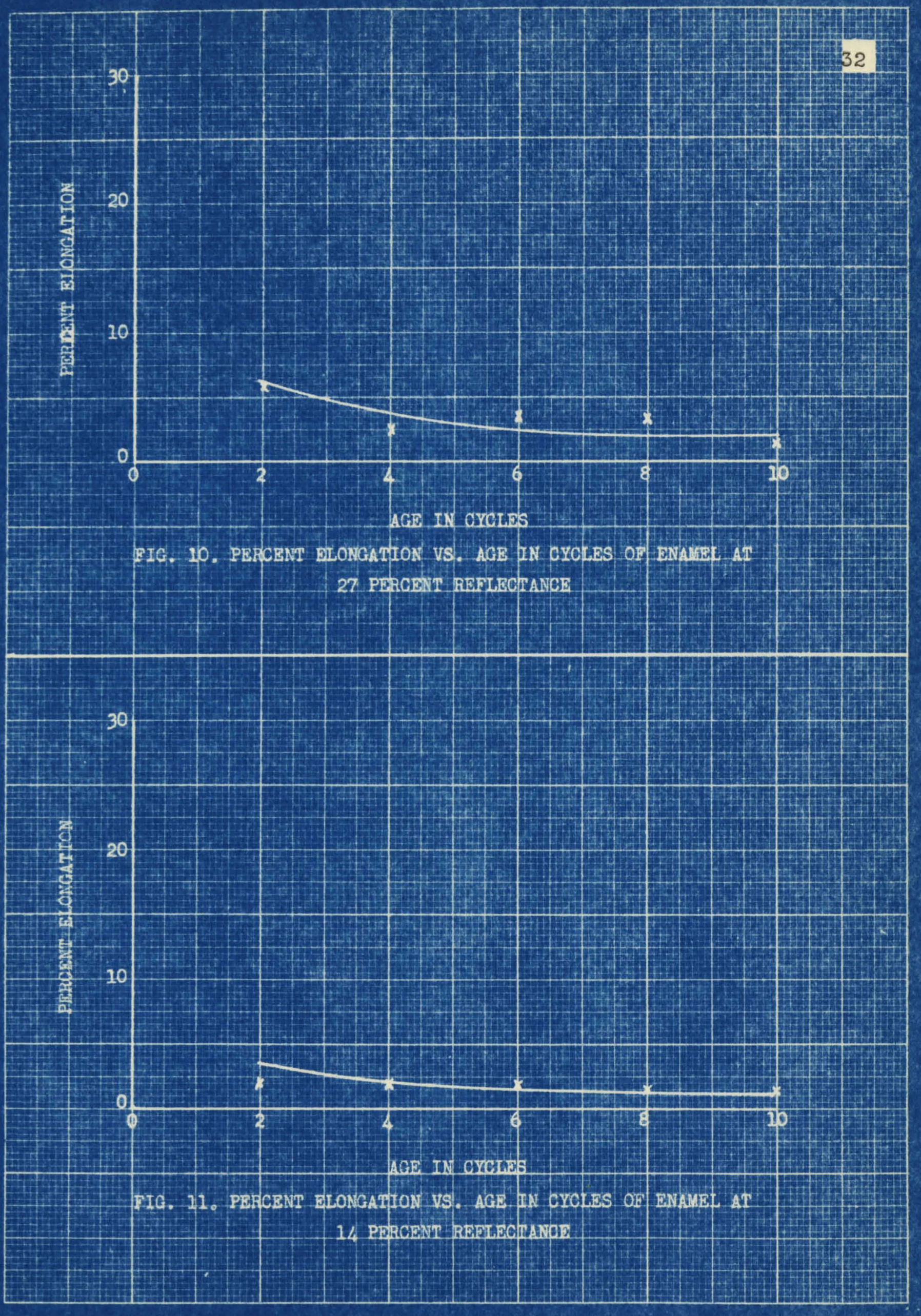


The other results were caloulated from the experinental wasurenta fording to the folloring wethods. The elougation was rad directiy in percont from the tosting suchin indicator alno the fila was 100me. long and the longation was given on the Indicator In mo. The volume porcent unoxtractable was oaloulatod by uae of the formule doveloped by zrnat and Eudaloy (5)

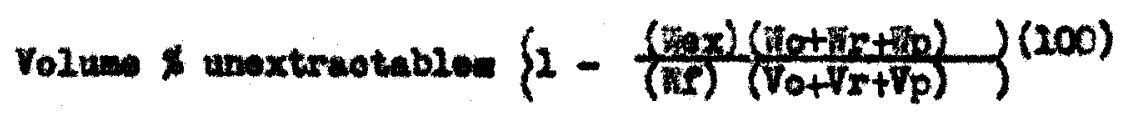

where Wox a wight of unoxtrectable metorlal, experiwontally dolarmined

II $=$ welght of film sample

Wo = woight of ofl in onamel sample

$W r=$ wight of roain in onumel oample

Tp = walght of piganent in snamel sample

To $=$ volue of oli in enemel amplo

Vr $=$ volume of reain in onamel ando

$\nabla_{p}=$ volume of plgment in anamel samplo

On examination of rigures 2-6, where percent

reflootance is plottod againat percent elongation at

difforent ages it is shown that the percent elongation tands to Increase as the percent rorlectence Inorages. This would indloate that the nore infrared abeorbed the greater the rigidity and consequently the lower the diatenalbizity.

Figures 7-11 show that at spproximataly conotant rolleotlon the percent elongation doorouses rapidiy only In ono cese and that at the higher refleotanos. The values at 818 rerlectence wore not Inoluded sinoe thoy wro detoralnod on a dirferent tenting mohine and are not comparable. 11gures 12-17 give the ountomary type obtained 


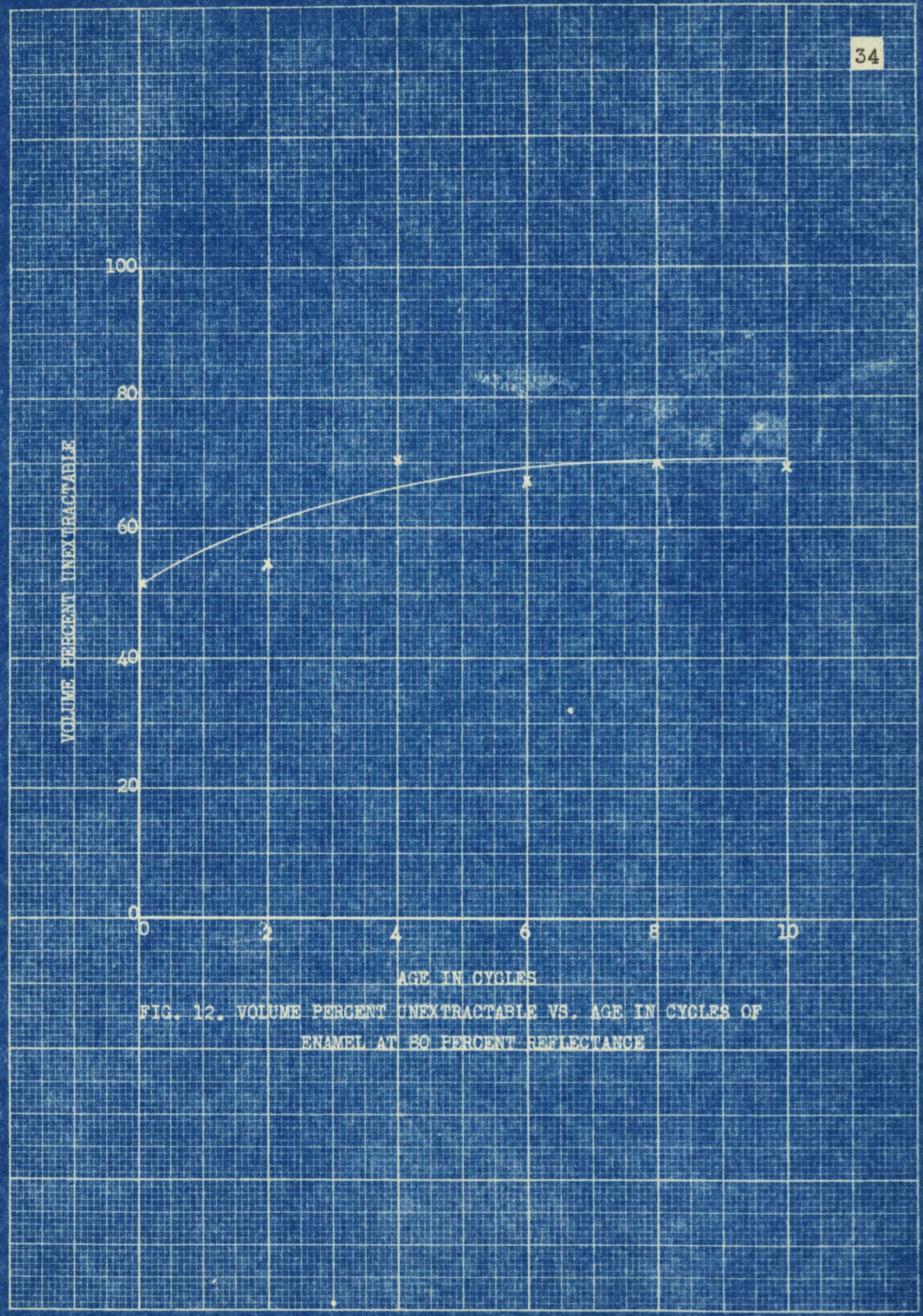




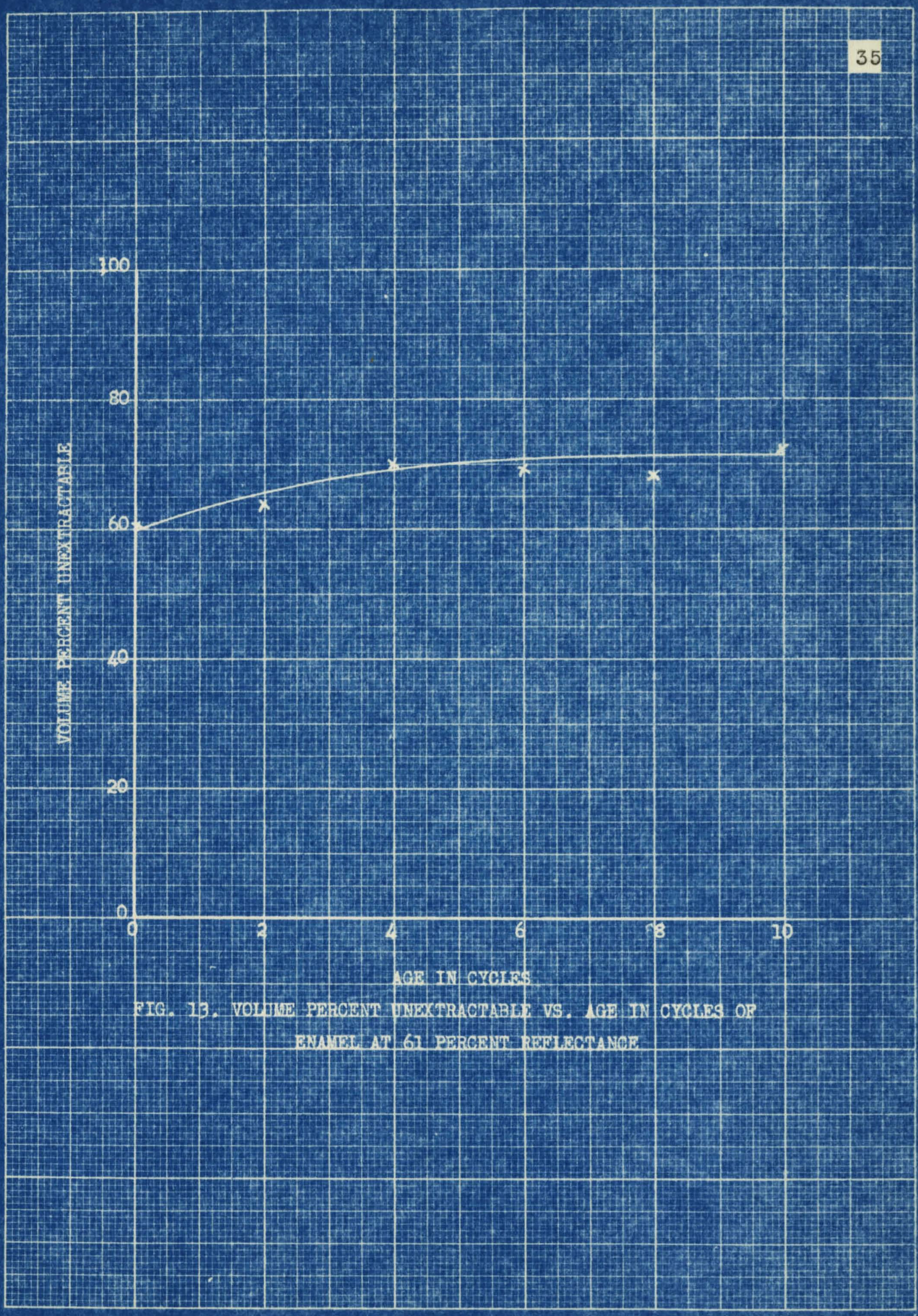




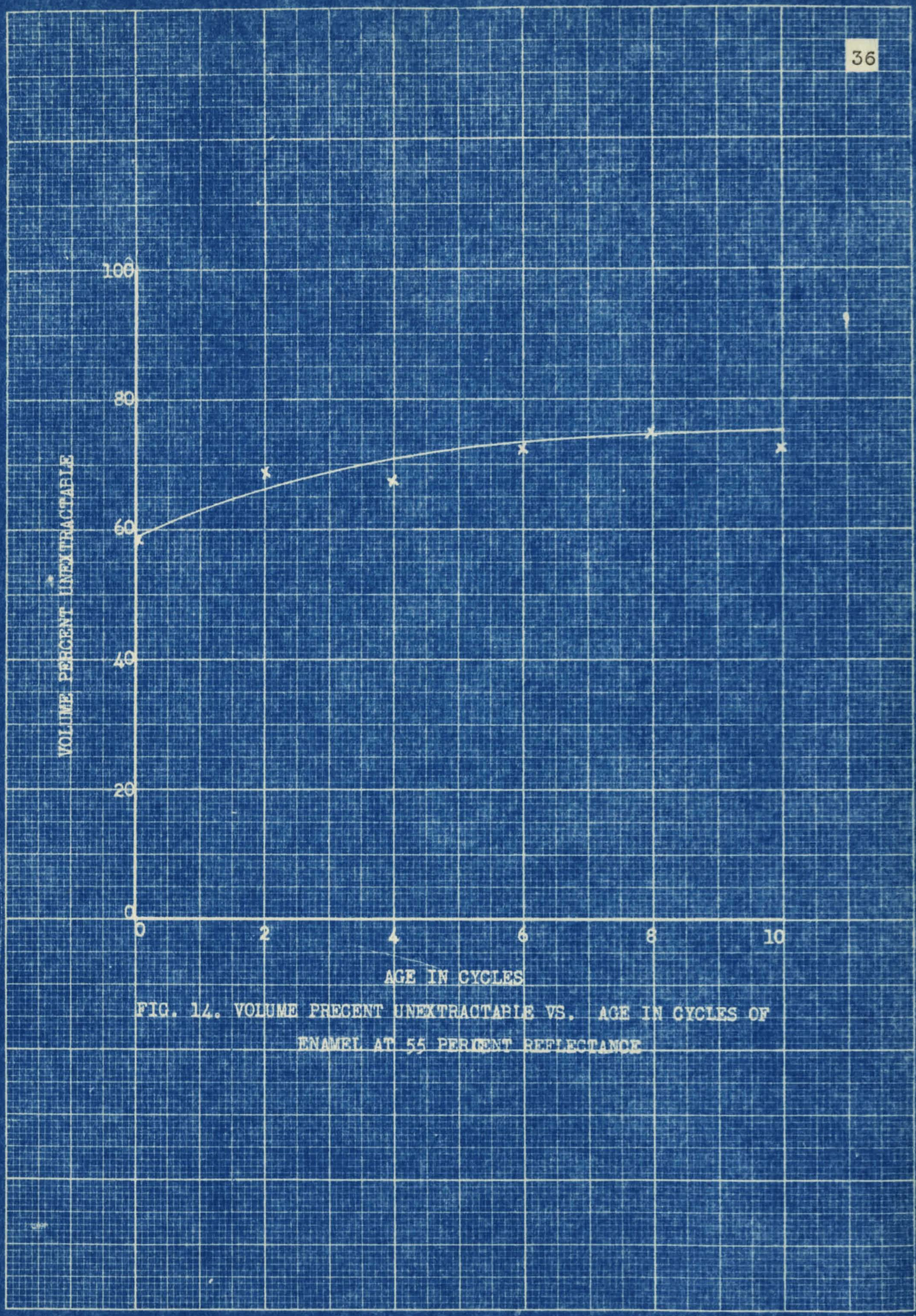




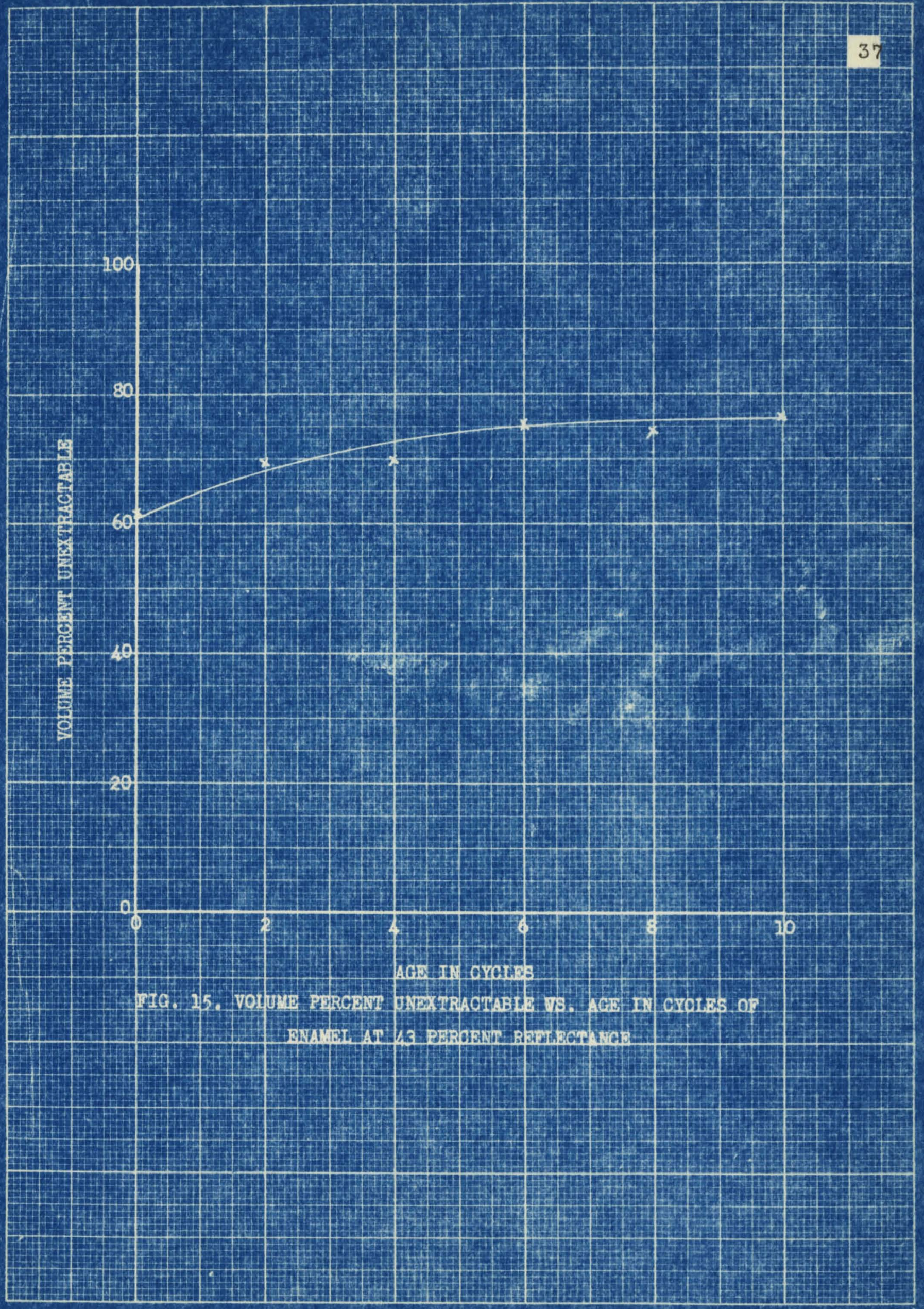




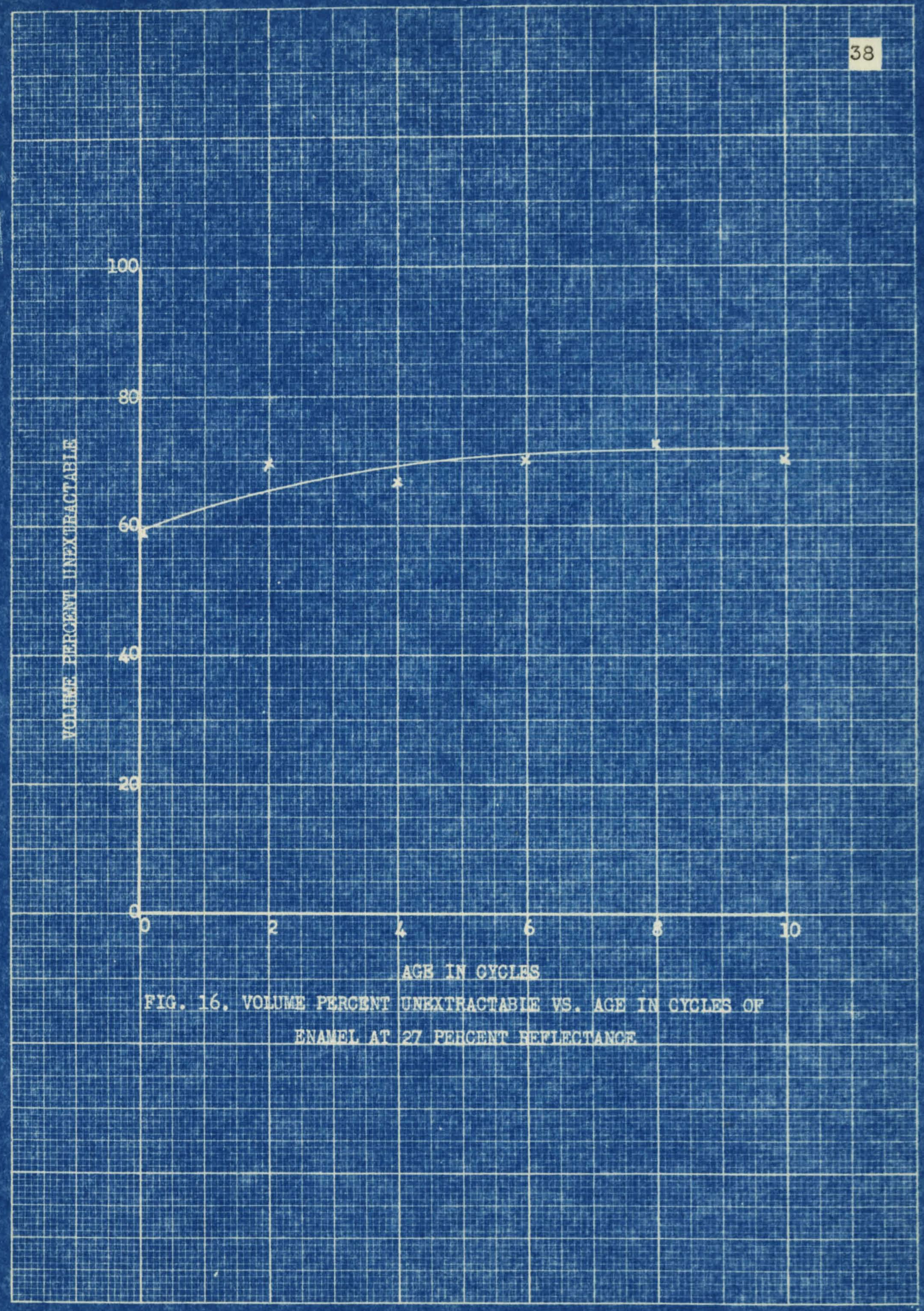




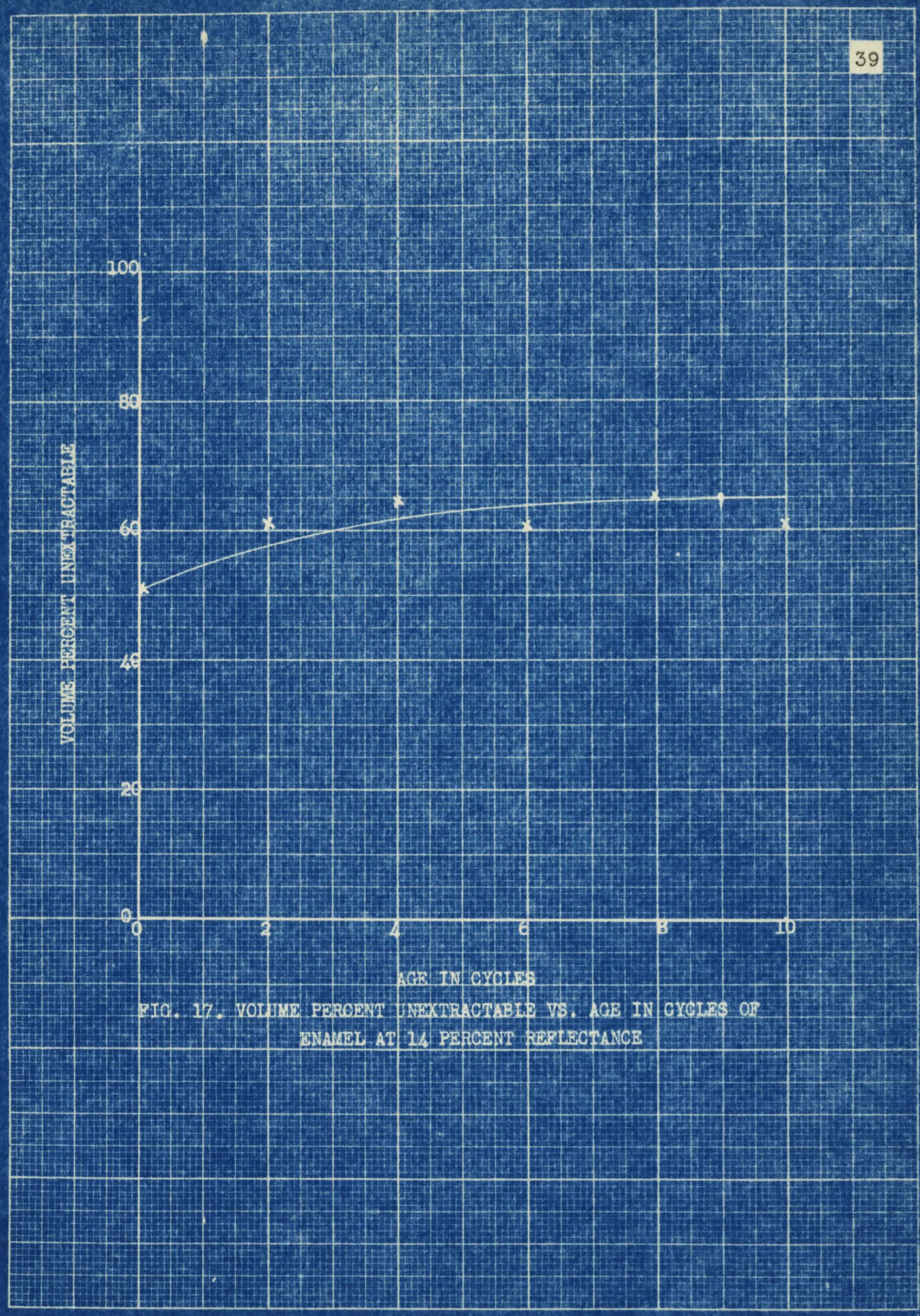


in provious lavatigations, however thase curres rian tare rapidy than that deteraingd ty Emst and Eudaloy (5) and do not reach the suse ilitimato polynar content. The rate of polymer formasion is grestest for the flims ohowing leart percentage renectance.

In general when ege va. volune peroent at:*xtractablo is plotto 23 in Figures 18-23, parabollo shaped ourve is obtained. They inatoa to that the Haximun polymer contant is resohed at a rafleotance of botwan 40 and 60 parcent at oompurabie ago. 


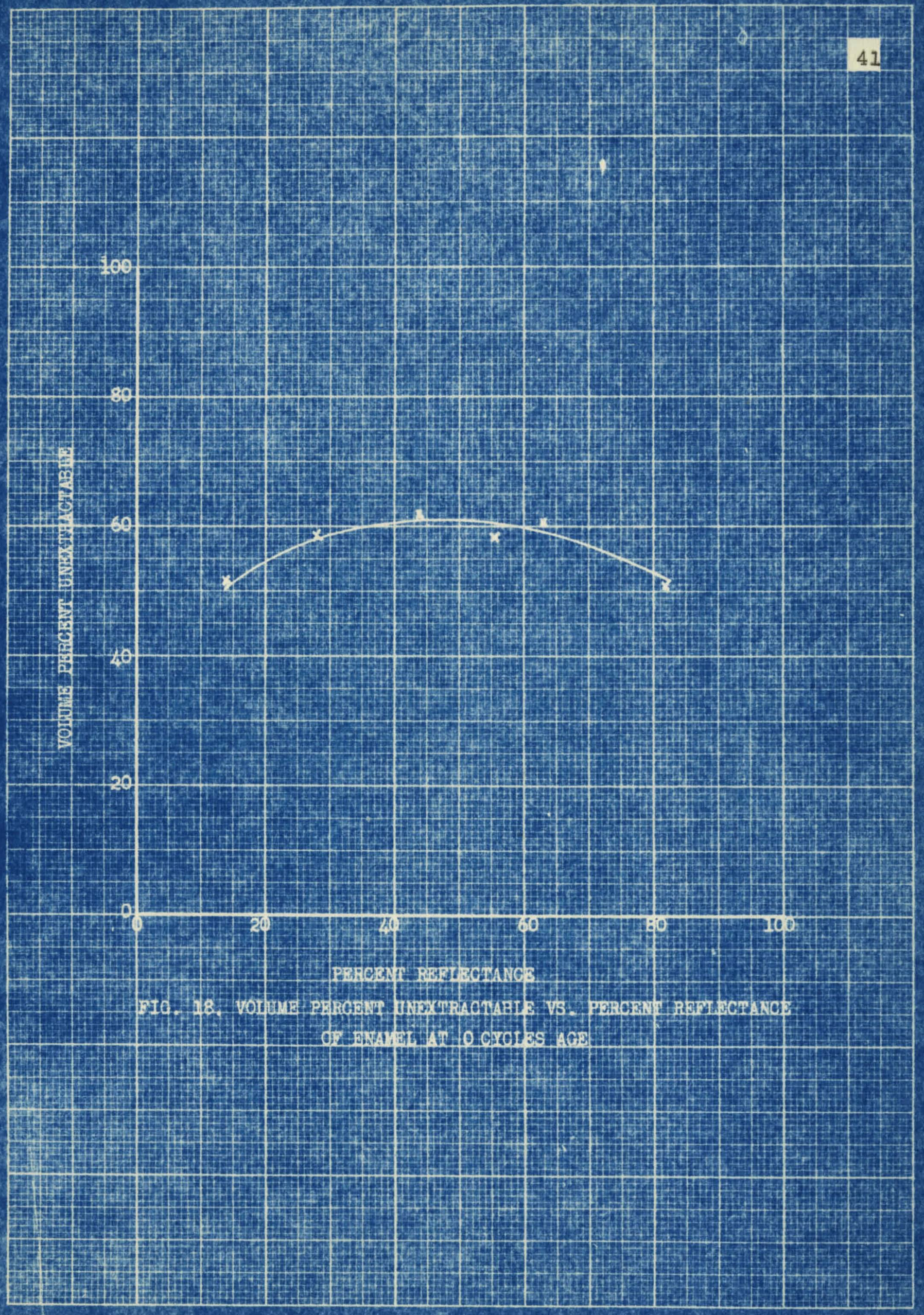




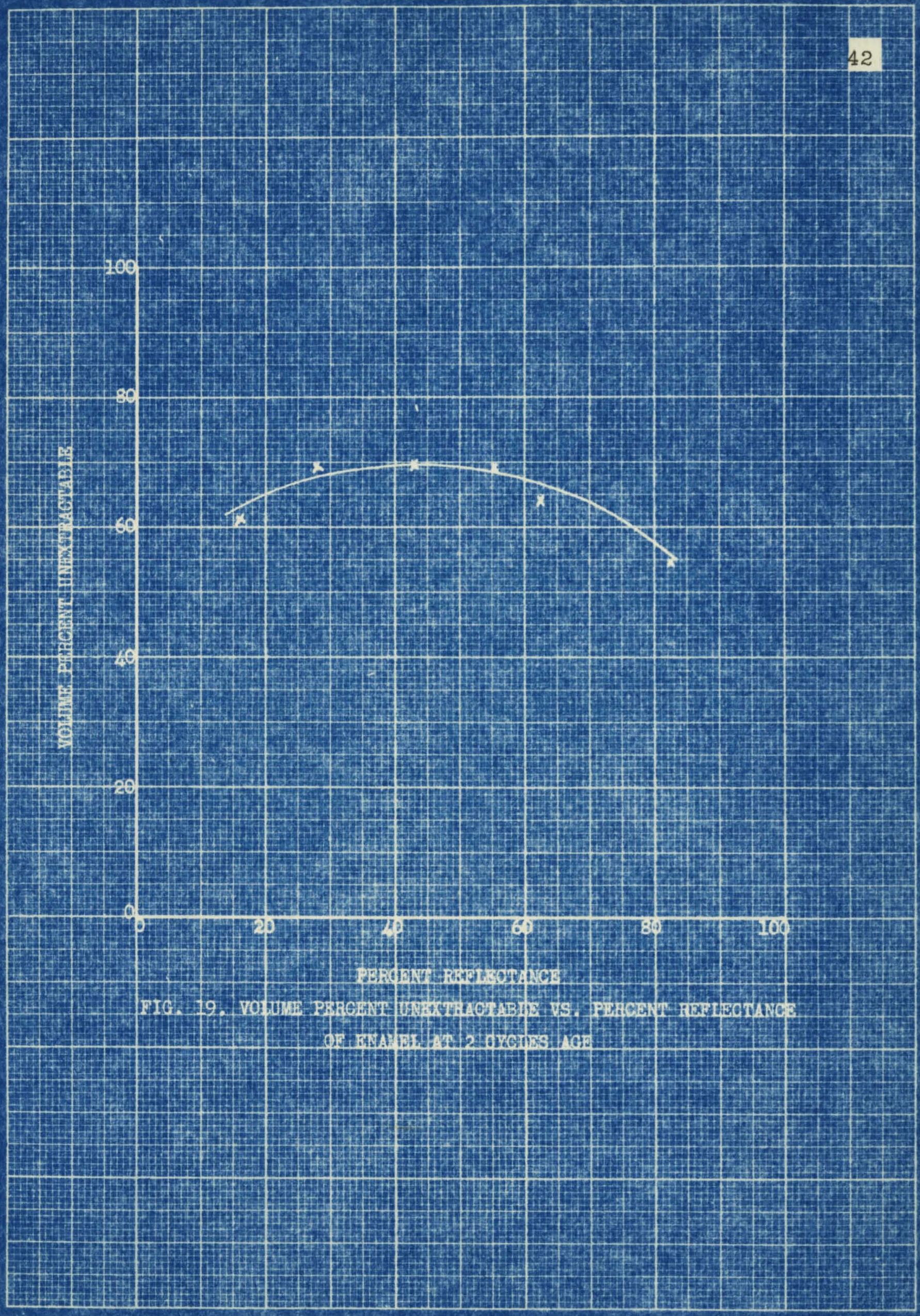




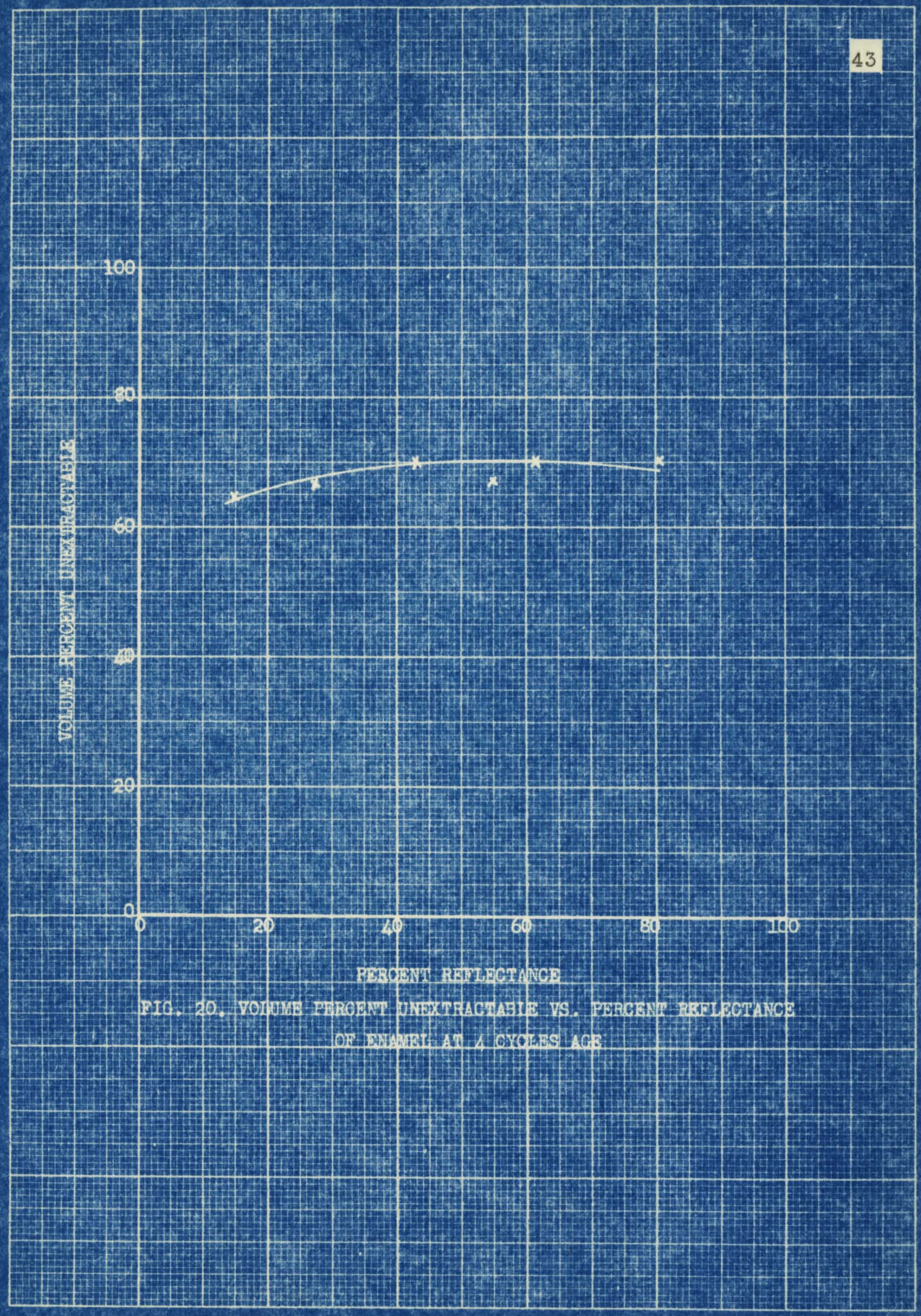




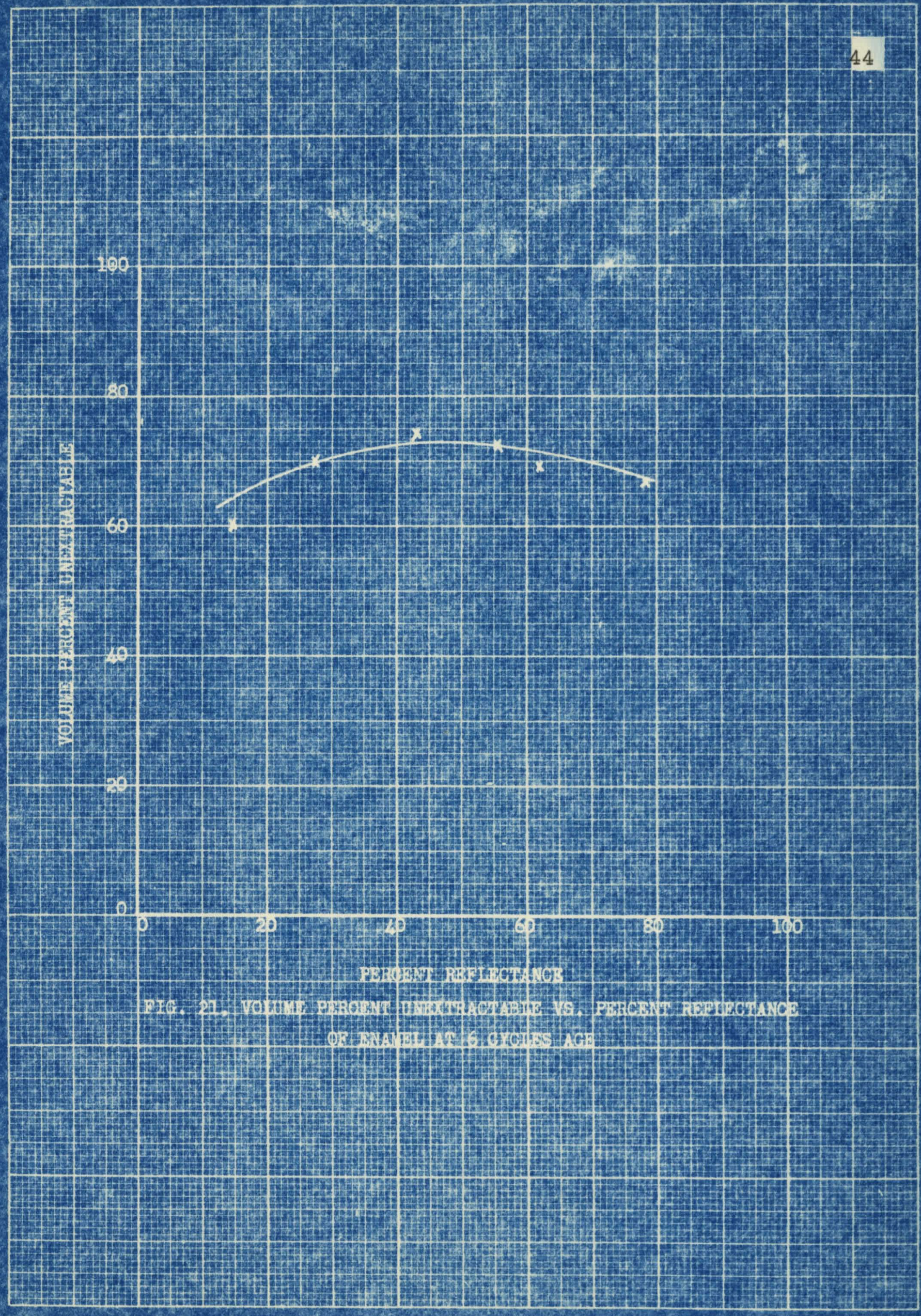




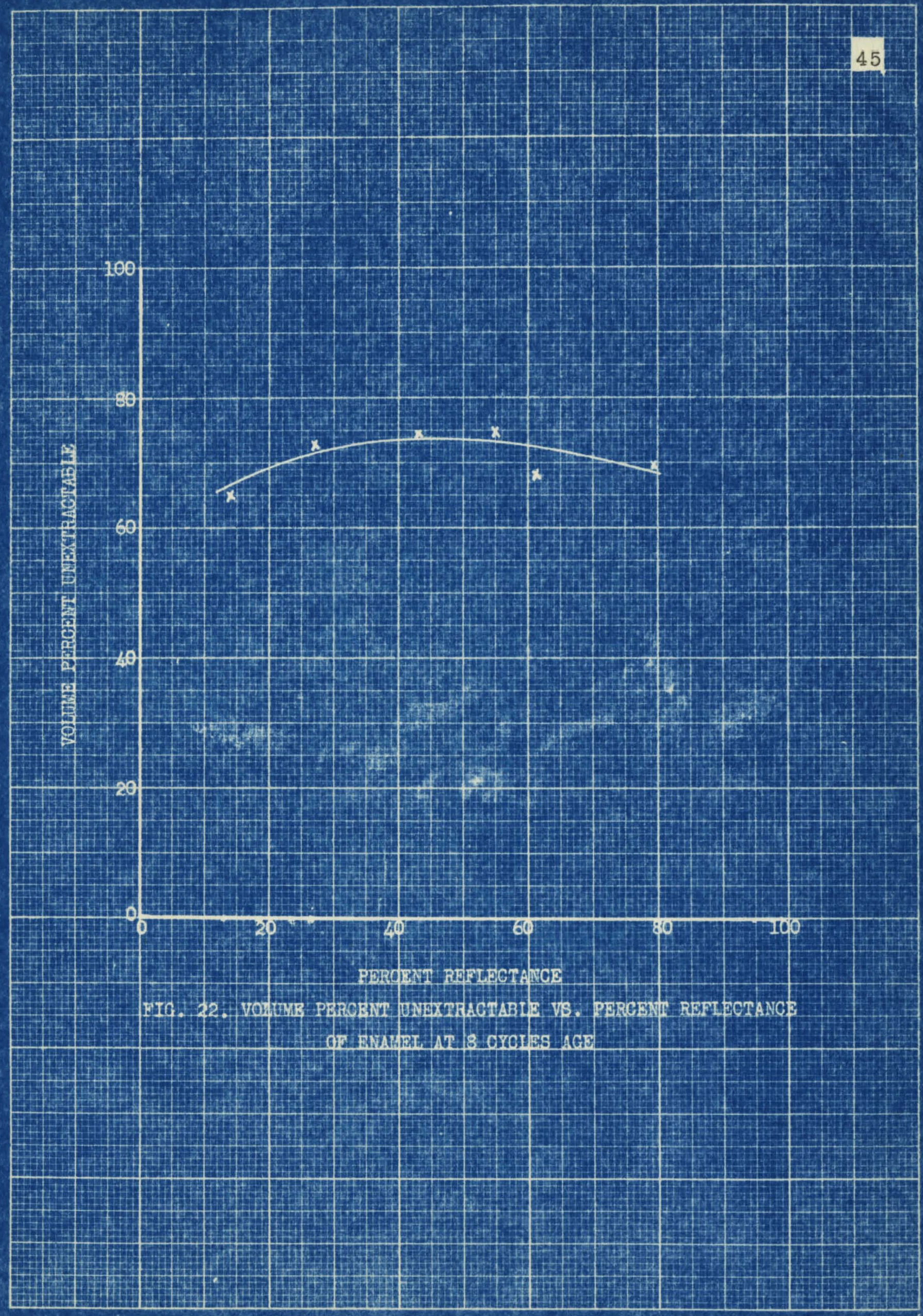




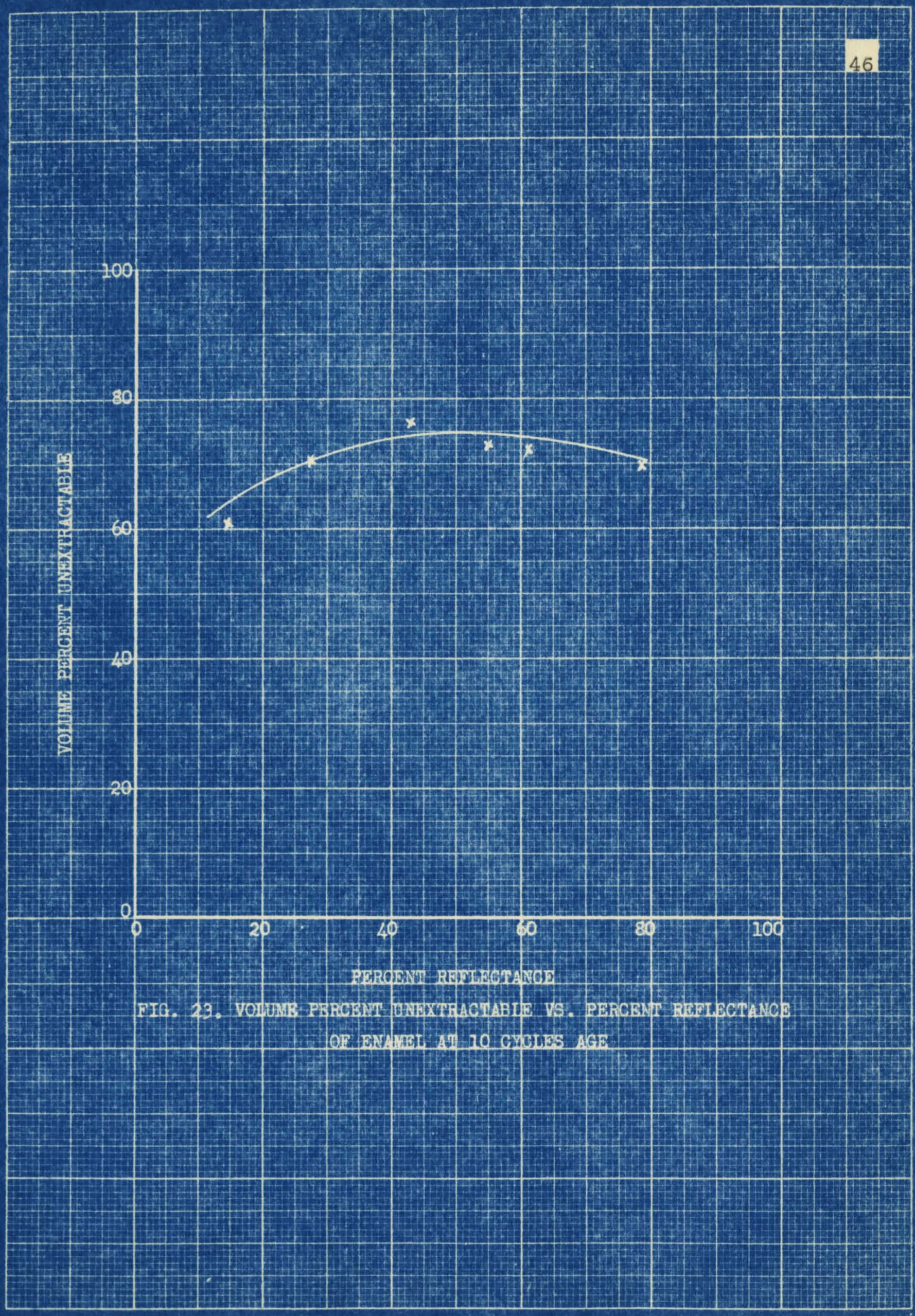


concLosIons 
In correlating these results with the previous inveatigations and wh inforation teken from the 21tarature of other investigators, the following conciusions ar reschod.

(1) Diotensibility of the film at various raflectences tends to sppromoh oonstant value as the iffe of the fIln inoreses, with the greatest distenulbillty being found in films of the highent reflectance. after the film has aged saterielly the variation in percent longation lo sall over large rarleotance range but mey be quite large in the early life of the f11.

(2) Polywor content at constant raflectance changes materimlly during the age of the flia, thus correlating well the diatenalbility data. The rate of polyer formation in the ariy 11fo of film is found to be greatest in those of loast refleotance but does not reach so high an ultimet value as for the flim of greater percentege reflectence. This suggenta a broukfirt down of the origtnal polymor formed at the lower reflectance as age 1norouse to offuet any further increses in polymer content. 
(3) From an analyele of 1 guras 18 to 23 it eppears that at conparable ages the polywer content of files -1th low reflectance is amall elther bocause of the antioxidant properties of the onall asount of lamplack or becumse of a rupture of wolecules due to the large amount of infrared astention aboorbed or to combin ation of both. As the percentage relfectunce increses, the polvaer content risea through a waxima which may analn be attributed to combination of the aformenthoned effects. As the peroentage ranectence lnoreases there is a deorece in polynar content whlch ma be cotssed by the fallure of the flin to recelve enough radiation of a dairable type to activat the formation of additlonel polymors whloh would be formed by cortain quantity of infrared radiation. 


\section{LITEATUEE CITED}

(1) Greenbeck and Holm, Ind. Eng. Chem., 33, 1058-68, (1944)

(2) Powarn, Ovarbolt, and Elm, 1b1d, 33, 1257-63, (1941)

(3) Ernst, F.C. and Mocuilikin, F.R., Am. Paint Jour., 4-D 25, 15, (1940)

(4) Ernst, F.C. and Lubbers, W.H., Tech. Proc. Annual Convention, Faint and Varnish Production Clube, page 131-46, (October, 1941)

(5) Ernst, K.C. and Euduley, 0.1., Paint, 011 and Chem. fioview, 104; 23, 102; 24, 18. (1942)

(6) Canguli, A.J., Indian Chew. Soc. 8, 753-65 (1932)

(7) Gerdzer, A.A., 'Ptyalenl and Chomical Examation of Palnts, Tarriahes, Leccuers, and Colours', pezes 94 and 99 , Inst1tute of Pelnt and Varnish Kowearch, thashington, D.C., (1939)

(8) Long, J.S., and MoCarter, W.5.H., Ind. Eng* Chew., 23, $786,(1931)$

(9) Rhodes, $7 . \mathrm{H}$. and Goldemith, H.8., 1bld, 16, 566, (1926)

(10) Horall, R.3. and Harks, S., J. 011 colour Chew. 14000., 12, 184 - 202, (1929)

(11) Long, J.S., kelneck, A.I.,., and Ball, C.L., Ind. Eng. Chom., 23, 786, (1931)

(12) Ring, J.L., Paint Varniab Production $\|_{g x}, 17,24$, (Ootobier, 1937)

(13) Moclookey, K.E., and France, w.0., Ind. Ing. Chem. $27,160-2(1935)$

(14) Kgan, J.D. and Shore, F.B., J. Am. Chem. Suc., 62, 3469, (1940)

(15) Overholt, J. and Els, A.C., Ind. Eng. Ches., 32, 1348-51, (1940)

(16) Ilunter, E. .3., Keseurch Paper EP 1345, U.S. Dept. of Com., National sureeu of Standards

(17) Fadiation oharacteriotios, National industrikl and therapeutic osrbons, Catelog section 4-4300, Mational Carbon Compen, Ine. 


\section{ICXIOTHDONEWrs}

The author wlehos to thank the Foderation of Paint and Varniah Production Clube for the grant that mado this Investigation possible. He expecinily wishos to exprese hls Indebtedness to the Pederation Soholurahip Committee, Hesars. K.J.How, Chairman, J.S.Long, P.O. Blackenore, E.J.Cole, B.A.Gerdnor, and Q.H.Prinst Jr. the weo wishos to expreas his appreolation to Dr. J.S.Long, Mr. Otto J. MILet1, and Mr. H.L.Boakes, nembers of the Loutaville Produotion Olub, who served as a local committee on renoarch for the redoration; to Mr. Charies I. Sacra, who ausioted in the exporimental work; and to the following companles for their donation of material and equipment:

Charlos R. Long Jr. Company, Loulevillo Kentuoky Color and Chamleul Company, Loudarlile Brom millianson robaceo Co. Louleville 
COUFREGMTION OF WOOD TESTING OF DIMEPHXIOLURA PLASTIC 


\section{LIST or TABLES}

Table

Page

2 Denelty of Noods oured at $10001 \mathrm{bes}$

Per sq. Inoh.

$69-70$

11 Denst ty of loods cured at $1001 \mathrm{bu}$.

por eq. Inch

$\boldsymbol{n}$ 


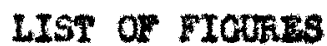

Figare

Page

1. Poottion of Bamples taken for Danalty

Deteringtions ..............................6 69

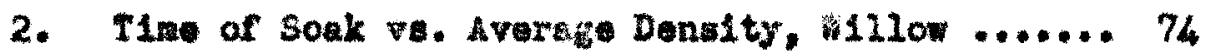

3. Time of Soak vo, Average Donulty, white Oak .... 74

4. Time of Souk rs, hrerage Denalty, Cottonwood ... 75

5. Time of soak va. Averege Done1ty, fad Oak ...... 75

6. Position ve. Density for w1210 at varlous

lengths of souking .................... 76

7. Position va. Density for fied Oak at various

lengthe of soaking ...................... 77

8. Position ve. Density for fats Oak at rarious

lengths of ganking ...................... 78

9. Poultion va. Density for Cottomood at various

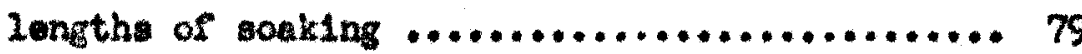




\section{AcknowLDousm}

The author wahes to acknowledge the kind asalatanco and belprul guidance of Dootor 0. C. HIIIms who difrected the following resseroh. 


\begin{abstract}
ASTMACT
Pour differeat woods are Inpregnated with a phonol-formaldehyde resin in aqueous solution. The density of the anples which had been oured at 100 and 1000 Ibs. per sg. Inch wse deterwined at varloas postions.

It was found that aterial increase of density wo obtained in all moods Investigated. No generalizetion oan be made for change in denalty with or acroas grain in the roods axained. Dimenstonal otabllity is roatly Inoreased by compregnation. the combination of compreation and lapregnation to form compragnatad woods offers now approwoh to the production of high denalty woods.
\end{abstract}


Ime oncrion 
The purpose of thia investigation sa to determine the effect of Impregnating wood wh realne and aubequently ouring the wood under preswure and at elevated temperature. In equeous solution of reain 1. ueed and peraltted to perweste the wood upon releave of presewze while the wood is lmeraed in the resin solution. The effect of time of soak and the presoure under which the resin impragnated wood is cured is atudied in relation to the rinal denalty. 
Hrsta Ion 
Varlous methods of changlng the density of wood by compresalon or impregnation have bean tried. The latest nethod is the use of a conbination of impregnation and comprestion, or as usuliy called 'compregnation'. In eddition to ralalng the dandty of the wood it is almo

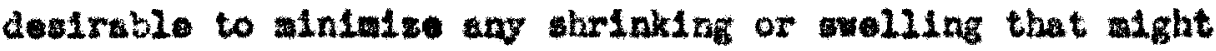
occur after the wood is in the final atate. Wost invest1getione heve leen conoerned wh the use of reaing to mininise the ohrinking and owelling of thin layers of wood which were uaed to atke plywood. In th1e fleld, the resin is used as adbenive as well an an Impregnating waterial.

Stan and seborg $(2,3,4,5)$ diwous the affect of verloue reain on the volume changes of wood and preaent result obtained when using resin trested wood in forming plyood, or laml-ated cowprosed wood. Super-prosed plywood has been Investlgated (1) by Bernhsrd, Perry, and Starn, this is a high donsity wood, a plywood in the true aonse of the word, and dorives 1t6 increawe in density frow the compresaton of the wood and the woe of reain adbest ves. 
62

THBORBrich 
Thare are rarlous mods of obtaining high denaity wood. One method resorts to the was of plywood and adhontres and proesswes undor a hlgh pressure, anothor method Involving plywood is to Inprognate the veneers with a resinous matorial and wth high pressure and elevated tomperature oauses the reain to act as bonding agent and adhesive. Tho bonding

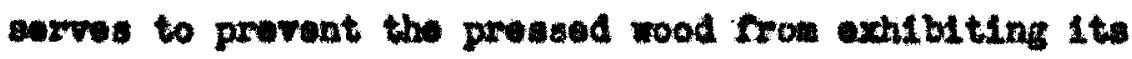
elast10 propertion upon releave of the pressure. The wethod of oompregnation, wherelo the wood ia firat Inpregnated with a resinous materlal and then compressed, offors a now appromeh to the produotion of high denst ty wood whioh will show anall volume ohange whon subjeoted to wde variations of moisture oontent of the ourrounding atmoophore. Staum and soborg (3) report a dofint to minlalaing of shriaking and swolling of wood treated with phonol-foraldehyde reulns. The method of comprognation Is to Impregnate tho wood with as large an amount as posalblo of a beat sotting rosin and aubeoquently to wet the rosin undor pressare at elorated touperatures.

The wod of treating wood with heat antting roains 1s to allow the resin to diffues throughout the fibere of the wood and then by a heat treatment to convert then to the insoluble state. Thle serves the purpose of 
making the wood loes pormeable to water and rulees the denalty. The eotting of the reain when the rood is compreseed also serves to bind the fibers more firmy and therefore makes the rood loas $11 \mathrm{kely}$ to undergo dimmalonal ohangen when proasure is reloaved. The wothods of Impregnating the wood with the reatn solution may vary conolderably. As in treating wood wh th preservatives, the wood may be subjoct to vaculu and then the reoln aolution foroed Into the wood undar preseure and at elovated tomporatures. Prossure Lon my also be wed to foroe the realn into the wood. Anothor mothod, whiah will be employed in this inveatigation, consists of saturating the wood with wator, by continual aoking or employing ellght presours, the saturated wood 15 then subjected to hlgh mochanieal preasure (1000 pal.) to force tho water out after whioh tho proseure is released from the wood while it is famerred in a rouln solution. obrlously thie method dopende upon the amount of water which oan be roplaced by the reatn and the elustic proportios of the mood atnoe the magnitude of preseure differsential oreated from the center to the outalde of the rood depende upon how moch the wook expends on releave of preasure.

The anount of aboorbed realn dopende to a great extent upon the struoture of the wood smployed. Other 
feotora afreoting the amount of wolution ebsorbed is longth of Imoraton, type of solution, risoosty of solution, and temperature. Secten (6) discusses the varlous type of woods and give a chart classifying the heartwood of various speoles with reupeot to penetrablifty. He pointe out that penotration nuy take plaoe in threo dreotions, navely. longt tuasnily, whioh is in the alrootion of the length of the tro trunk; radialy, whah is in the direotion of the radius of the tres: and tungentielly or ciroumferentially. which is in the dirootion of the anmual ringes. Consrally the greatest panatrution is found to be Iongltudinally becuse of the sunlier number of odl will nocessary to penotrate. Froil dutu of Nacloan the angmitud of penstretion should dearease in the follawing order, red onk, cottonmood, and white oxk. Briclason, Sohalts, and Cortner (7) have obtained date on the permeability of varlous wooda and they how that wht te oak heartwood is one of the least permeable woods. They used presaure difforentiale up to 20 ibe. per sq. Inoh sorose ploce of wood one an. thiok. The anount of colution abeorbed may be Increased by partial rupture of cell wall when subjeoted to hlgh proagum thus deoreasing matarlelly the roistano to pentration. 
DXERIMENAL 
APPARATUS

The main piece of apparatus used was a hydraulio press with thermostatically operated, electrically heated platens. Th1s preas, wade by the Charles B. Francis Company, is hand operated with platens one foot square and a platon of 50 aquare inches surface area. It is posalble to obtain up to 50 tons total load on this preas. The press is gupplied wh a pressure gauge reading from 0 to $20001 \mathrm{ba}$. per eq. Inch on the surface of the piaton and graduated in 4016 . Increments.

Other apparatus included a clanp for holding the presaure on the wood when it was transforred to the resin solution for the release of preasure. The lower part of the elamp is a pleoe of steel which has belts placed in each corner, heads fluah wth the urface. The upper part of the clanp has a raieed and machined surface on which pressure can be applied. Two lots in each ond of the upper part were so placed that the bolta from the lower plece could fit into thon. The sample was placed in the olanp and pressure applied, the presure beling retalned on the nood by tightening the nuts on the bolts. A shallow pan, slightly larger than the clamp was used to hold the reain solution as the pressure was released from the wood. A Sargent Electric Drylng Oren was used to pre-oure the samples. 
A pressure oylinder was used to saturate the wood with water, pressure of 15 lbs. per square Inch used, and the samples soaked up to 72 hours. BA VATRRIALS

Samples of cottonmood, willow, and red and white oak were used. They wore approximately $4^{\text {" by }}$ 3/7-16" by 1" before soaking. The resin used for impregnation was Amberlite PR 23, a phenol- formaldahyde resin manufactured by Resinous Products and Chomical Company. This resin is water coluble and was used in aquoous wolution in conoentration of $30 \%$ solids content by weight. PROCEDUR:

The wood sanples were placed in a pressure vessel, water of about $140^{\circ} \mathrm{F}$ added, and $151 \mathrm{bs}$. afr preasure applied. The water was changed frequently. The samples wore weighed before and after soaking with water. The samples were prossod to one-half their original sise, if possible, or until a maximum of 1000 1bs. per sq. Inoh was reached, they were then clamped in the holdor, placed under the resin solution for a pertod of $1,5,10,30$, and 60 minutes and 12 hours. The samples were welghed after afr dry1ng, pro-oured in an oren at $140^{\circ} \mathrm{I}$ for $10-12$ hours and again welghed. 
Aftar oven Arytng the anplog were ploced in the hot press, at a temperature of $250^{\circ} \mathrm{F}$ and presaure appl1ed, 200 and 2000 lbs. por sq. Inch wore uged. The aamples wore hald at this tapporature for 20 cinutes and then allowed to cool in the pross to $175^{\circ} \mathrm{F}$. The compregneted amples were than aum to produce $1 / 2$ inah equaxes for dotormination of denalty. The samplea for donat ty dotermination ware so whosen as to give throe daterminations with the grain and two acroas the grain, ase Figure I, In addition to a ample from the oenter of the block. Dimenslona of the cubas were taten with vornier callpar, and they woro wathed on an andytioal balanoe. 


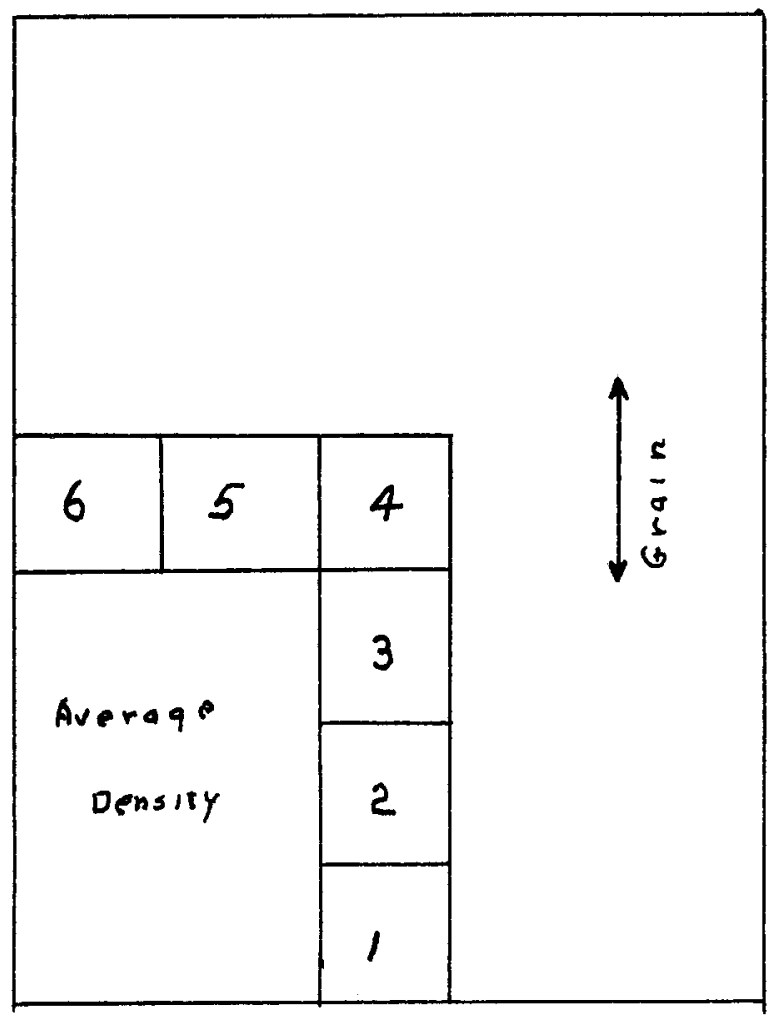

Pic. I. Position of Samples taken for Density Determinetions 
DEUSITY OF WOODS CUERD AT 1000 LAS. PGE SQ. INCH

\begin{tabular}{|c|c|c|c|c|c|c|c|c|}
\hline 1000 & TIAB OF SOKL & $\triangle V E R A C E$ & & ABSITY & POSIT & & & \\
\hline & MTHUTES & DEASITY & 1 & 2 & 3 & 4 & 5 & 6 \\
\hline cortom OOD & $\begin{array}{r}1 \\
5 \\
10 \\
30 \\
60 \\
720\end{array}$ & $\begin{array}{l}0.917 \\
0.979 \\
0.956 \\
1.015 \\
1.133 \\
1.162\end{array}$ & $\begin{array}{l}0.983 \\
1.068 \\
1.025 \\
1.075 \\
1.300 \\
1.280\end{array}$ & $\begin{array}{l}0.978 \\
0.981 \\
0.977 \\
0.976 \\
1.210 \\
1.168\end{array}$ & $\begin{array}{l}0.946 \\
0.959 \\
0.956 \\
0.872 \\
1.200 \\
1.125\end{array}$ & $\begin{array}{l}0.939 \\
0.983 \\
0.966 \\
0.981 \\
1.195 \\
1.112\end{array}$ & $\begin{array}{l}0.902 \\
0.939 \\
0.946 \\
0.989 \\
1.158 \\
1.132\end{array}$ & $\begin{array}{l}0.869 \\
0.948 \\
0.899 \\
0.956 \\
1.085 \\
1.062\end{array}$ \\
\hline RED OLK & $\begin{array}{r}1 \\
5 \\
10 \\
30 \\
60 \\
720\end{array}$ & $\begin{array}{l}1.235 \\
1.075 \\
1.005 \\
1.015 \\
1.133 \\
1.162\end{array}$ & $\begin{array}{l}1.178 \\
1.085 \\
1.035 \\
1.172 \\
1.133 \\
1.178\end{array}$ & $\begin{array}{l}1.235 \\
1.110 \\
1.009 \\
1.237 \\
1.180 \\
1.200\end{array}$ & $\begin{array}{l}1.292 \\
1.090 \\
1.251 \\
1.258 \\
1.213\end{array}$ & $\begin{array}{l}1.289 \\
1.080 \\
1.278 \\
1.305 \\
1.227\end{array}$ & $\begin{array}{l}1.340 \\
1.152 \\
1.070 \\
1.265 \\
1.223 \\
1.192\end{array}$ & $\begin{array}{r}11.368 \\
1.065 \\
0.998 \\
1.105 \\
1.151 \\
1.085\end{array}$ \\
\hline TILOW & $\begin{array}{r}1 \\
5 \\
10 \\
30 \\
60 \\
720\end{array}$ & $\begin{array}{l}0.948 \\
1.003 \\
1.011 \\
1.137 \\
1.023 \\
1.190\end{array}$ & $\begin{array}{l}1.038 \\
1.044 \\
1.011 \\
1.118 \\
1.084 \\
1.192\end{array}$ & $\begin{array}{l}1.182 \\
1.033 \\
1.043 \\
1.215 \\
1.190 \\
1.228\end{array}$ & $\begin{array}{l}1.190 \\
1.072 \\
1.145 \\
1.190 \\
1.241 \\
1.208\end{array}$ & $\begin{array}{l}1.230 \\
1.067 \\
1.197 \\
1.187 \\
1.228 \\
1.205\end{array}$ & $\begin{array}{l}1.175 \\
1.065 \\
1.172 \\
1.253 \\
1.218 \\
1.200\end{array}$ & $\begin{array}{l}0.936 \\
1.978 \\
1.059 \\
1.145 \\
1.038 \\
1.102\end{array}$ \\
\hline WHITE OAX & $\begin{array}{r}1 \\
5 \\
10 \\
30 \\
60 \\
720\end{array}$ & $\begin{array}{l}1.142 \\
1.138 \\
1.175 \\
1.210 \\
1.200 \\
1.062\end{array}$ & $\begin{array}{l}1.115 \\
1.161 \\
1.162 \\
1.230 \\
1.230 \\
1.077\end{array}$ & $\begin{array}{l}1.160 \\
1.182 \\
1.178 \\
1.212 \\
1.282 \\
1.096\end{array}$ & $\begin{array}{l}1.160 \\
1.212 \\
1.193 \\
1.288 \\
1.245 \\
1.110\end{array}$ & $\begin{array}{l}1.185 \\
1.203 \\
1.185 \\
1.288 \\
1.258 \\
1.182\end{array}$ & $\begin{array}{l}1.188 \\
1.145 \\
1.310 \\
1.258 \\
1.152 \\
1.136\end{array}$ & $\begin{array}{l}1.135 \\
1.145 \\
1.175 \\
1.195 \\
1.188 \\
1.082\end{array}$ \\
\hline
\end{tabular}




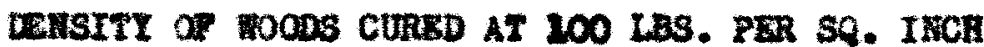

\begin{tabular}{|c|c|c|c|c|c|c|c|c|}
\hline \multirow[t]{2}{*}{ W00D } & \multirow{2}{*}{$\begin{array}{c}\text { Trus of sonx } \\
\text { HINUTss }\end{array}$} & \multirow{2}{*}{$\begin{array}{l}\text { A VERACR } \\
\text { DERSITY }\end{array}$} & \multicolumn{4}{|c|}{ DEASITY at posITron } & \multirow[b]{2}{*}{5} & \multirow[b]{2}{*}{6} \\
\hline & & & 1 & 2 & 3 & 4 & & \\
\hline Corrominood & $\begin{array}{l}1 \\
5 \\
10 \\
30 \\
60\end{array}$ & $\begin{array}{l}0.581 \\
0.582 \\
0.702 \\
0.770 \\
0.763\end{array}$ & $\begin{array}{l}0.556 \\
0.573 \\
0.730 \\
0.738 \\
0.755\end{array}$ & $\begin{array}{l}0.566 \\
0.570 \\
0.734 \\
0.760 \\
0.765\end{array}$ & $\begin{array}{l}0.570 \\
0.630 \\
0.734 \\
0.873 \\
0.842\end{array}$ & $\begin{array}{l}0.569 \\
0.574 \\
0.723 \\
0.736 \\
0.722\end{array}$ & $\begin{array}{l}0.563 \\
0.561 \\
0.722 \\
0.744 \\
0.706\end{array}$ & $\begin{array}{l}0.542 \\
0.572 \\
0.702 \\
0.703 \\
0.720\end{array}$ \\
\hline RED OAK & $\begin{array}{r}1 \\
5 \\
10 \\
30 \\
60 \\
720\end{array}$ & $\begin{array}{l}0.861 \\
0.805 \\
0.826 \\
0.783 \\
0.789 \\
0.938\end{array}$ & $\begin{array}{l}0.868 \\
0.806 \\
0.798 \\
0.805 \\
0.816 \\
0.953\end{array}$ & $\begin{array}{l}0.864 \\
0.812 \\
0.820 \\
0.804 \\
0.829 \\
0.952\end{array}$ & $\begin{array}{l}0.865 \\
0.820 \\
0.819 \\
0.809 \\
0.829 \\
0.959\end{array}$ & $\begin{array}{l}0.863 \\
0.799 \\
0.804 \\
0.811 \\
0.792 \\
0.939\end{array}$ & $\begin{array}{l}0.868 \\
0.806 \\
0.816 \\
0.794 \\
0.783 \\
0.949\end{array}$ & $\begin{array}{l}0.848 \\
0.805 \\
0.820 \\
0.799 \\
0.767 \\
0.931\end{array}$ \\
\hline MrLLo: & $\begin{array}{r}1 \\
5 \\
10 \\
30 \\
60 \\
720\end{array}$ & $\begin{array}{l}0.692 \\
0.702 \\
0.810 \\
0.776 \\
0.723 \\
0.746\end{array}$ & $\begin{array}{l}0.673 \\
0.694 \\
0.803 \\
0.802 \\
0.729 \\
0.726\end{array}$ & $\begin{array}{l}0.659 \\
0.699 \\
0.863 \\
0.798 \\
0.728 \\
0.735\end{array}$ & $\begin{array}{l}0.712 \\
0.719 \\
0.811 \\
0.816 \\
0.787 \\
0.808\end{array}$ & $\begin{array}{l}0.668 \\
0.687 \\
0.793 \\
0.817 \\
0.779 \\
0.717\end{array}$ & $\begin{array}{l}0.674 \\
0.690 \\
0.796 \\
0.806 \\
0.774 \\
0.7720\end{array}$ & $\begin{array}{l}0.685 \\
0.669 \\
0.770 \\
0.766 \\
0.702 \\
0.700\end{array}$ \\
\hline WHITE oux & $\begin{array}{r}1 \\
5 \\
10 \\
30 \\
60 \\
720\end{array}$ & $\begin{array}{l}0.807 \\
0.801 \\
0.816 \\
0.332 \\
0.846 \\
0.830\end{array}$ & $\begin{array}{l}0.790 \\
0.788 \\
0.802 \\
0.831 \\
0.830 \\
0.903\end{array}$ & $\begin{array}{l}0.769 \\
0.801 \\
0 .-8 \\
0.836 \\
0.825 \\
0.909\end{array}$ & $\begin{array}{l}0.792 \\
0.799 \\
-0.839 \\
0.8324 \\
0.919\end{array}$ & $\begin{array}{l}0.787 \\
0.791 \\
0.813 \\
0.836 \\
0.816 \\
0.907\end{array}$ & $\begin{array}{l}0.788 \\
0.803 \\
0.819 \\
0.836 \\
0.837 \\
0.904\end{array}$ & $\begin{array}{l}0 .-79 \\
0.790 \\
0.816 \\
0.827 \\
0.835 \\
0.870\end{array}$ \\
\hline
\end{tabular}


72

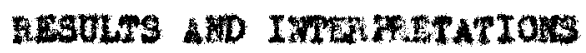


From Flares 2 to 5,1 is ovident that within exporimental orror the density Inoreases with the time of woaking. The change in donsity wth tiwe is allobtly more repld for tho material trested at the higher preseure, this 1s probubly not due eatirely to the axount of remin absorbed but way be attributed in part to the waterials of h1gheat reain content belnf moat easily pressed.

The inorease in density is found to be greatest In the cottomood, followed by w110w, white and then red okk. These resulta were to be expeoted since the atructure of the willow and cottomood is ouch that a large anount of material be taken in axong thelr flbers. The red and Wite osk hes grain atructure whloh offers great resiotance to the permetion of 1lquida.

Upon Inspection of 71 zurea 6 to $9,1 t$ appore thet no generalization cen be ade for the entire group. At 1000 1bs. per sq. Inoh pressure the 1110w done give a decresse in denalty as the center if approsched along the grain, thi is to be expected under normal olrcumatances. In the other waples, both wth and corose the grain at 1000 lbe. per aq. Inoh, the denstty is in general found to be greatest at the ceater and dropping off rapidy as the edge is approached. This by be attributed to several 
1,5

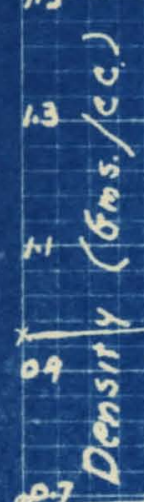

27

FIG. Z TIME OF SOAK VS. AVERAGE DENSTUY WILLOT:

x -1000 1bs. per sa. Inch

- 100130. per aq. inch
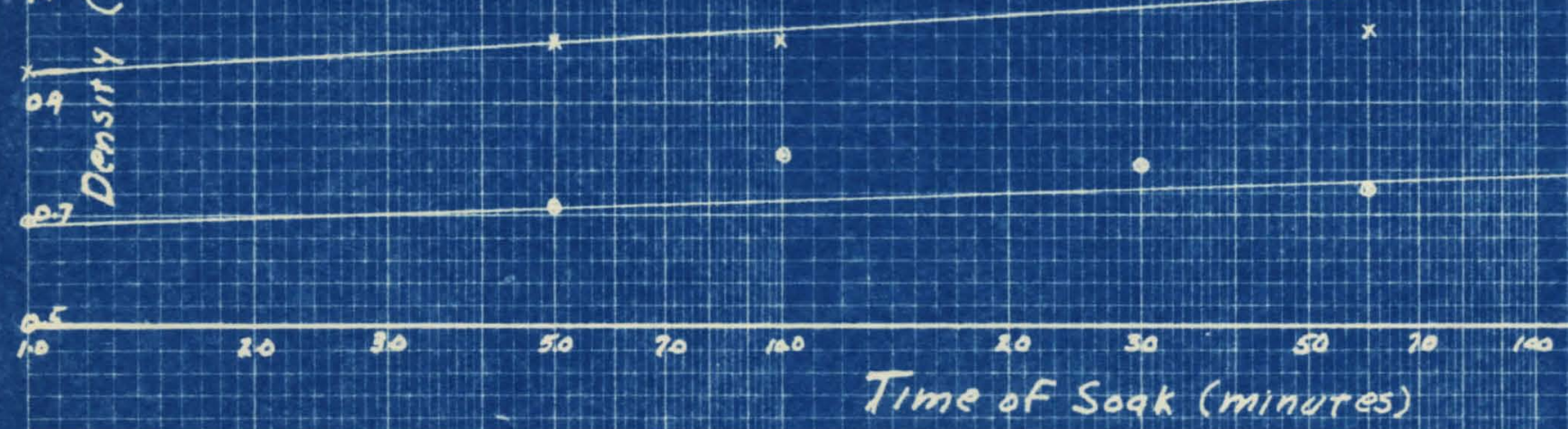

200

800
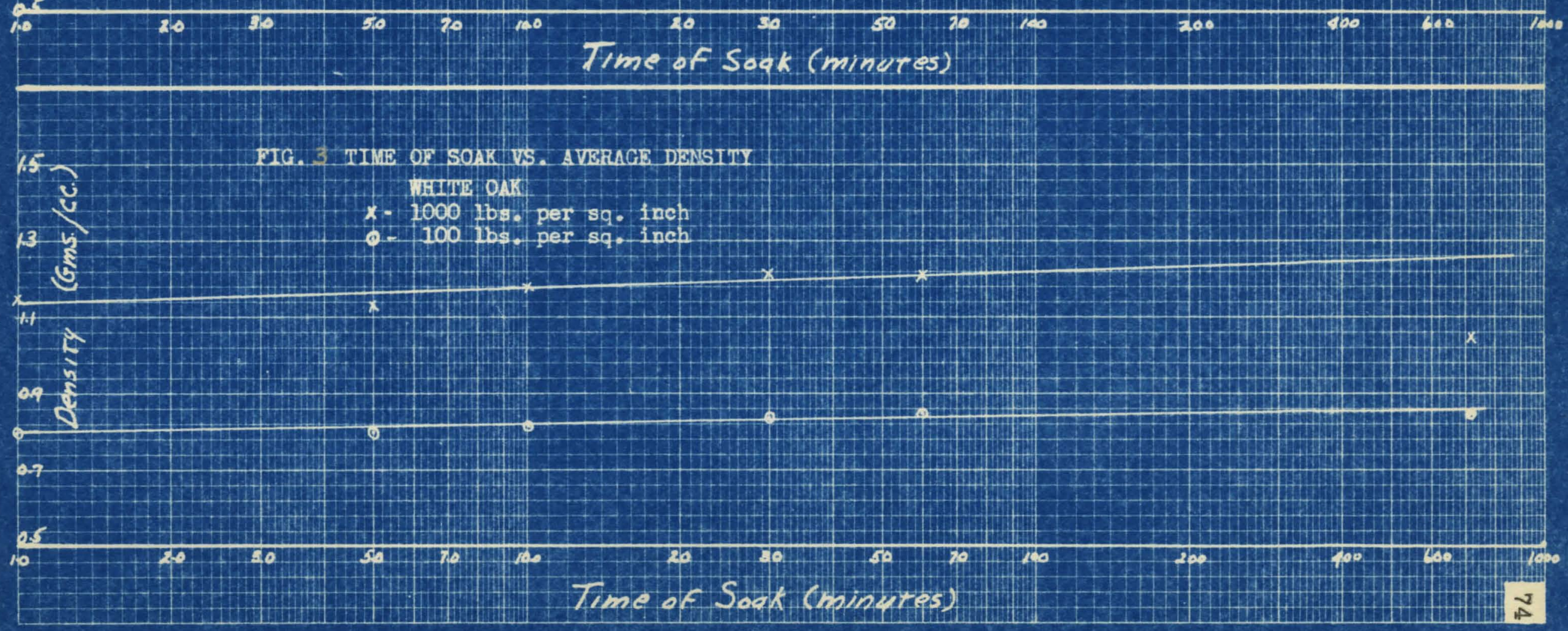


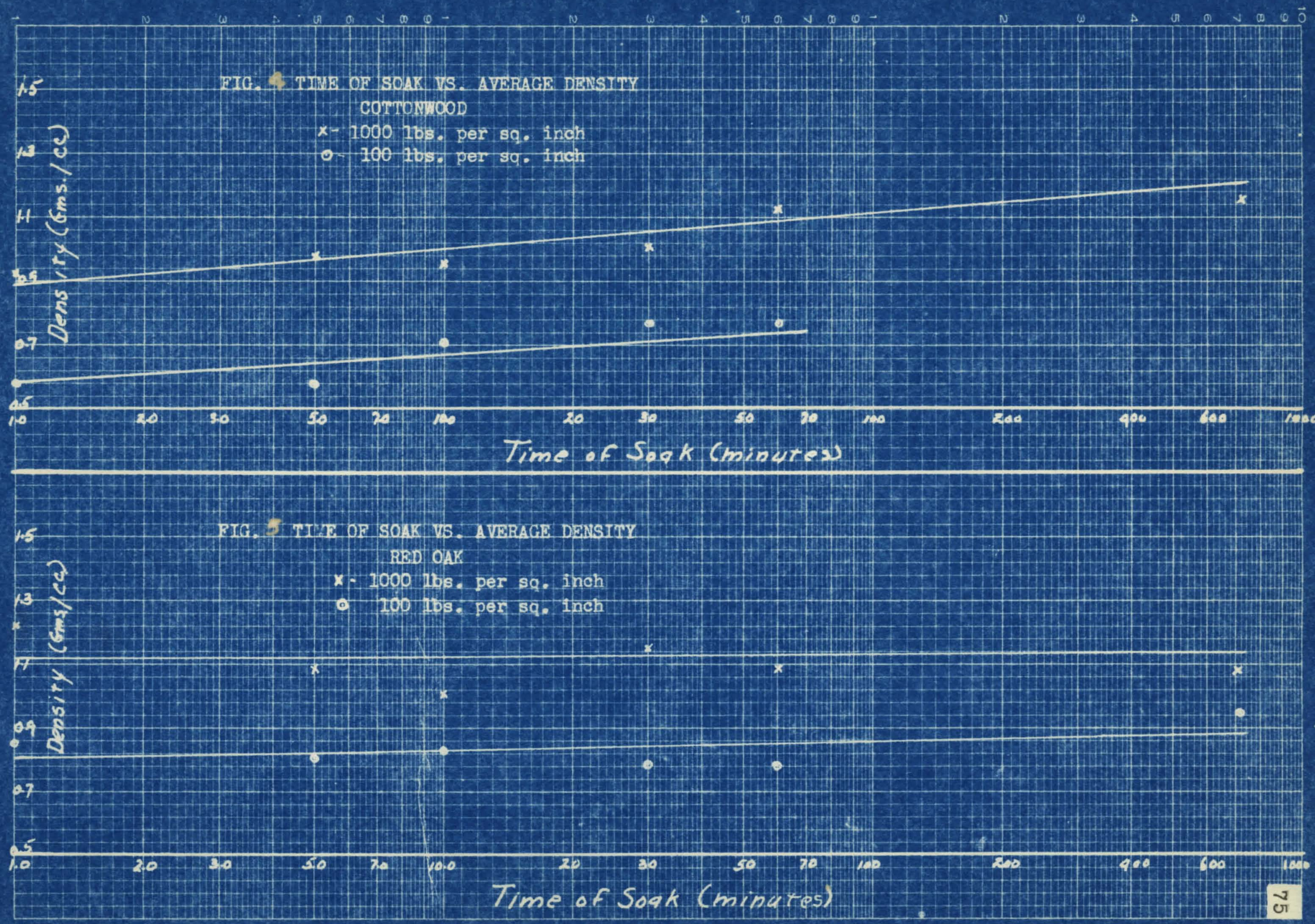




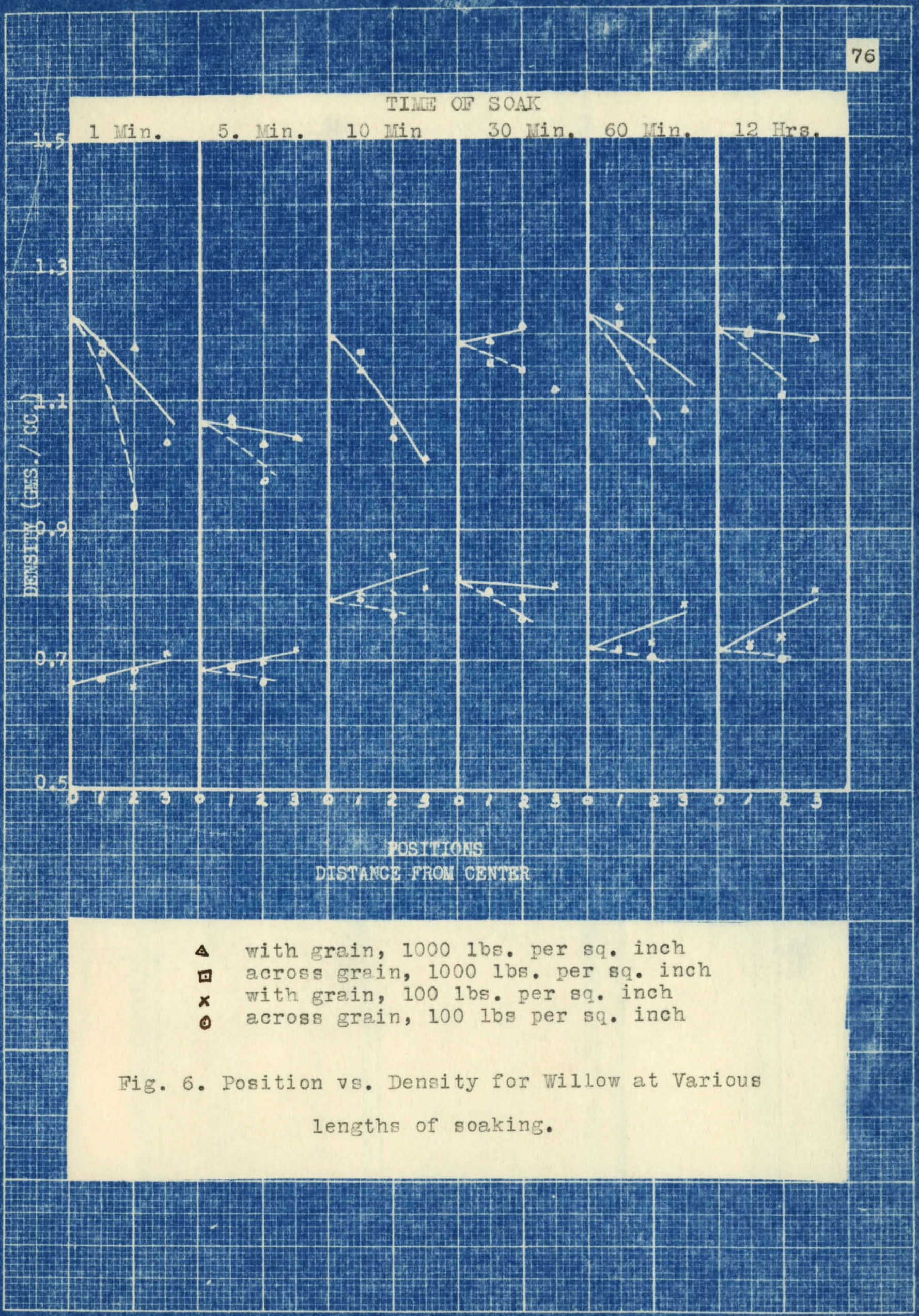




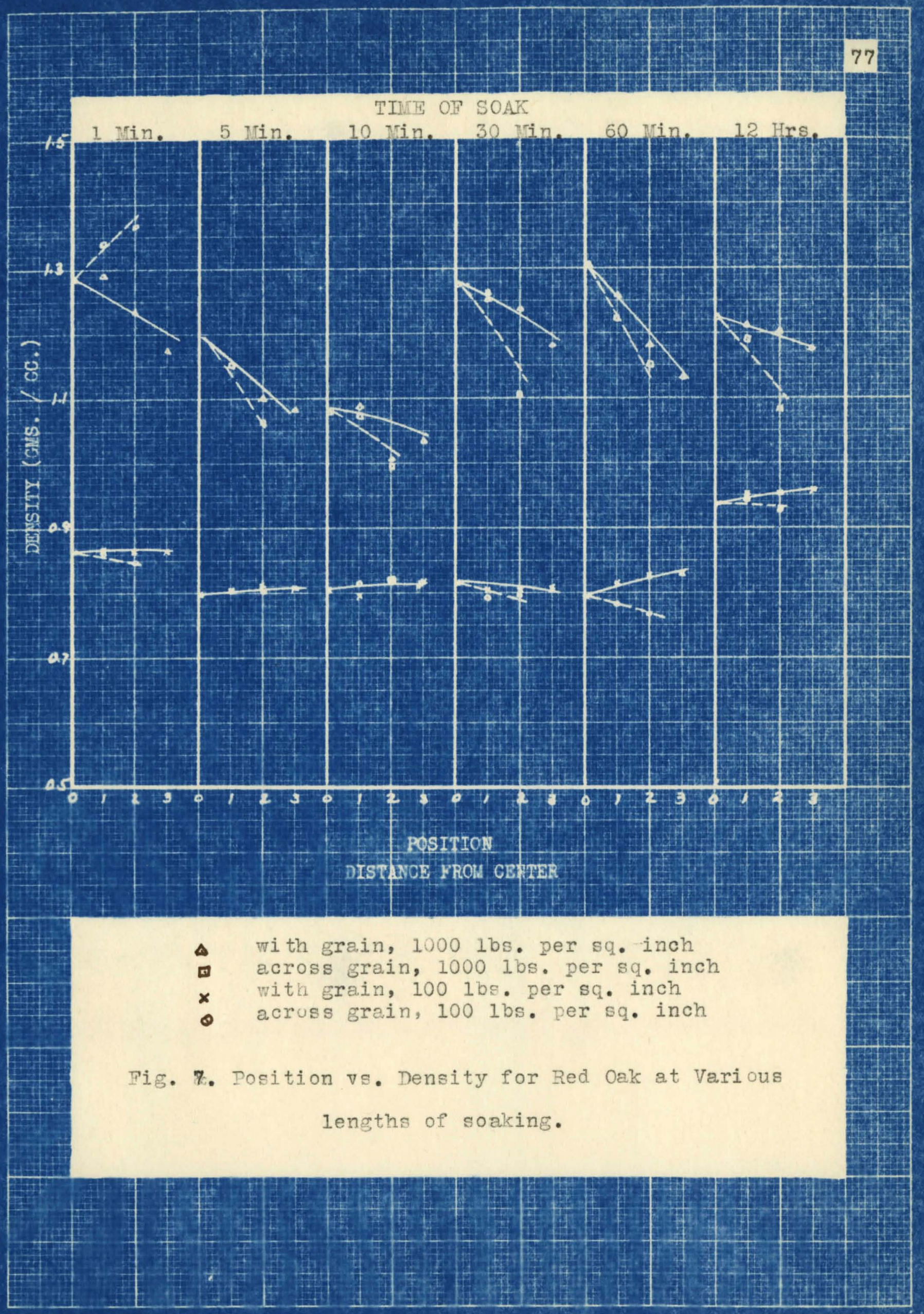




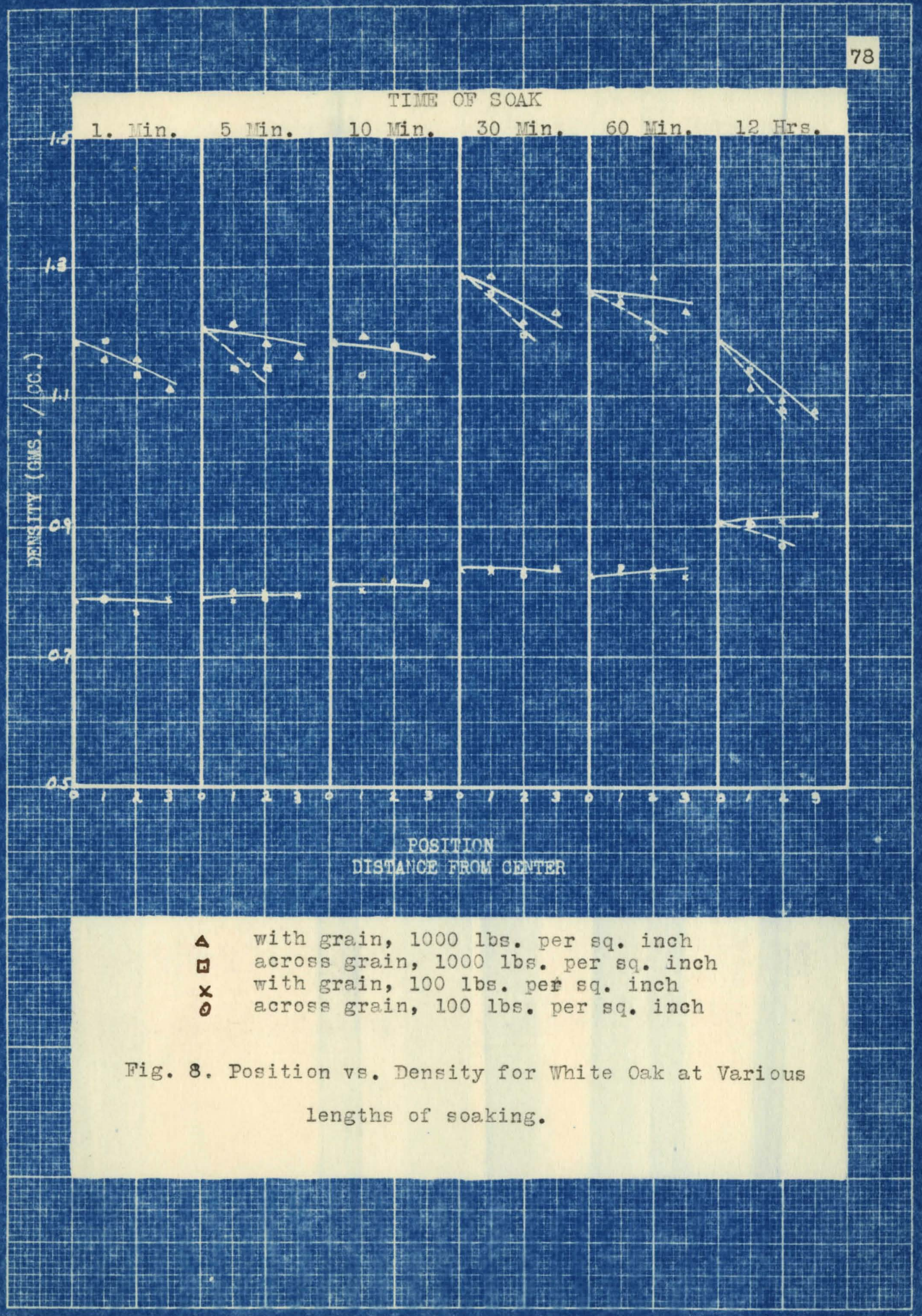




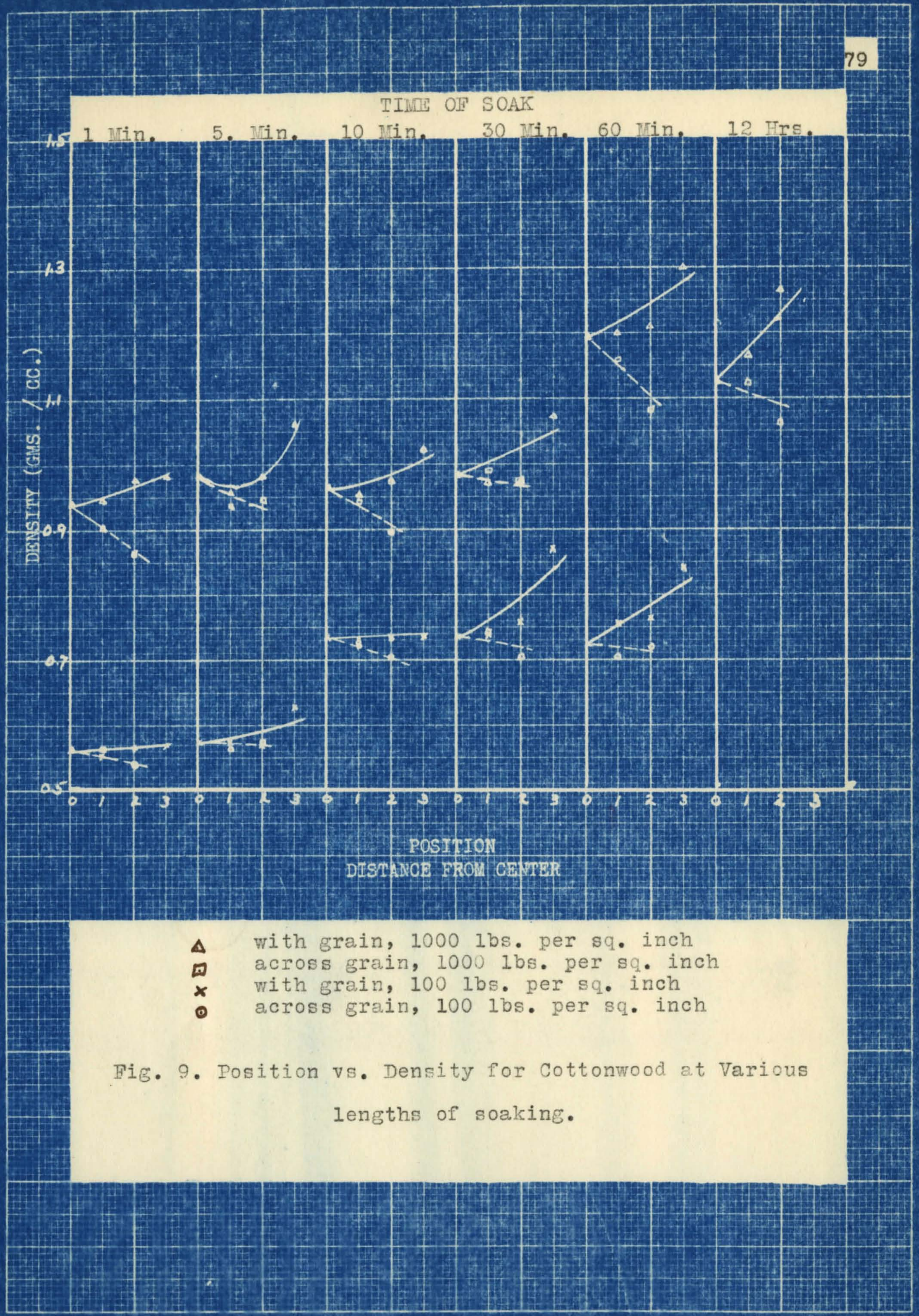


effectat 1 , there was notlocable vaporisution of the resin as detected by the odor onitted during the curing a well as the decreese in weight; 2 , exudstion was considerable in some of the samples; 3, end and alde offects may have bean great enough to introance slight errors becuse of a difrerential in preseure.

Lt the lower preasure of 100 Ibs. per aq. Lnch the tenelty in general wa cbarved to increase as the Age weaproached along the grain. This indicates that not wo auch vaporization occurred and is what would be expected to oocur. The deasity caross the grain exther decreased with distance from the centor or reasined practically the sawe as the variation in denalty 1 th the grain. This indleates in the whito cak and to sowe extent in the red oak that the anount of resin perwesting the wood is nearly the wame acrose the frain as along the grain. 
82

conclusions 
There ie found to be a dorint to inerease in density wh the length of coak. This is what would be expeoted to happen; however, the length of soak whlah would be nost economioally foastble remains to bo determined.

The denalty of the wood is found to be materm 1ally ohanged beause the realn decroases the elastlot ty of the wood and Inorasses the dimensional stabilsty. The wothod of Impregneting 1s ouch that no large presare trouting veasole are requtred for infecting the resin oolution. The greatest denatty in compregnated woods 18 found in the wood of moatevt original donstty and seons to Indiante that the asein nunotion of the resin is not the addition of weight but the ablilty to bond the compreseed fibers and koep then frow rotaining their original atzo.

Untform denalty throughout Iarge pleoes of wood way be nore noarly obtained than would by Indicated from the experimental date because of the largo and effect of the experinentel samples. The denosty obtalned o1 11 depend upen the preseure under whloh the realn 19 cured. The raxletion in the experimentel date resulted from the equipwont used afno it was impousible to acourately control prosaru in the procesuling. Soes of the seuples were therefore conpresend more than others before impregnating and during ouring period. 
(1) Bernhard, Porry, and stern, Wechenict Ingineering. V01. $62,189-95(1940)$

(2) Stam and sobore, Trens. K.I.Ch.E., 37, 385, (194,1)

(3) stand and 3oborg, Ind. Ent. Chan., 28, 1165, (1936)

(4) Stam, 1b1d, 27, 401, (1935)

(5) Staw and Seborg, 131d, 31, 897, (1939)

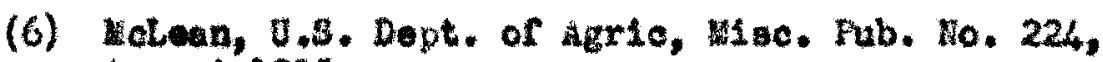
Auguet 1935

(7) Erickson, 3chmste, and Cortnor, Vniv, of Minn., Tech. Bull. 122, Ju1y 2937 
84

TESTINO OF DIMETHKLOLUREA PLASTIC 


\section{LIST O TABLES}

Table

Pago

1 Stebility of Dimothylolurea Plastio in

Diatilled Nater at Varlous Tempuratures

91

11 stab121ty of Dimothylolures Plestio in 


\section{LIST OF FTCURES}

Figure

Page

1. Percent Inorenev ve. Toaperature of Unaurfaco Pinstio in Distiliod Water

92

2. Porcont Inorease ro. Temperature of Surfacod Plastio in Diotillod Fator 92

3. Peroent Increate vo. TIme of Unsurfaced Plastio in 4 Peroent Salt Solution

4. Peroent Inorease va. TIm of Surfaoed

Plantio in 4 Peroent Salt Solution 
Im ondorrow 
The effect of water upon a Almothylolurea plastic is to be daterninod. This plastio is made by heating a mixtur of 4 parti dinothylolurea and 5 parts wood ebaringe under preseure and at a tomperature of about $145^{\circ} \mathrm{C}$. The proosdur for aking the plastio is from privats counteation of Dr. G.C. W12lians. The stabl1ty of this plastio when Intarsed in water of various tomperatures and the erfoct of exposure to salt mater for prolonged portoda 111 be datamined. 
EXPERTIEHILL. 
The tout block fron whioh the samples wore taken mosured to $x 5$ Inches and the oapples for testing wore out so that thoy approxdmatod oubses. S1X samplos from various test blooke wre tuken to give a represenstive analysis. The semplea wre dinoneloned Wth a vernier mioromotor and wolghed on an analytioul balanos. One sot of samples was unsurfaced, 1.0., as propared, while the othor had been ourfaced by canding until the origtinal glese had dlappoeared. The semplos wore Imooreed in an orlonewoyor flawk and kopt at the deatrod temporature for a partod of $24 \mathrm{hra}$. aftar whith thoy wore blown dry, welghod, and dimonelonod.

A second sot of samples was lmanoed in a 4 *alt solution at room tomparature and the same procedure followed in determinlng moluture and volume change. The tomporature was controlled by plaolng a thermonoter in the orlonwoyor Plask and placing the ontire ascombly in an oren whloh had boon regulated for the doulred tomperature. Equilituriun of the mater Ith the oven temperature was obtalned before plecing the auples in the wator. 


\section{TABT: 1}

Stability of Dimothylolure plastio in Distillod water At various tomperatures

\begin{tabular}{|c|c|c|c|c|}
\hline \multirow{3}{*}{$\begin{array}{l}\text { Toup. } \\
{ }^{2}\end{array}$} & \multicolumn{4}{|c|}{ Avg. Percentage Increase } \\
\hline & & & $\operatorname{sux}$ & \\
\hline & Volumes & WeIght & Volume & กี้อ \\
\hline $\begin{array}{l}68 \\
100 \\
125 \\
150\end{array}$ & $\begin{array}{r}5.47 \\
12.01 \\
15.18 \\
29.80\end{array}$ & $\begin{array}{r}7.22 \\
13.40 \\
17.92 \\
22.95\end{array}$ & $\begin{array}{r}6.25 \\
11.69 \\
17.41 \\
35.00\end{array}$ & \\
\hline
\end{tabular}

TABLZ 21

Stability of Dimothylolure plautio in $4 \%$ Salt solution at room temperature.

Time of Inmervion (days)
Average Poroentage Inoreage

Ungurfenged Volume Volught

6.90
11.25
12.77
14.16
24.26
24.30
-9.93

6.90 10.57

11.99

14.18

15.02

16.55

30

1.03 sumenend

Volune WeIgtt

$\begin{array}{rr}7.45 & 7.68 \\ 11.65 & 12.25 \\ 13.66 & 13.29 \\ 15.63 & 14.49 \\ 16.69 & 14.69 \\ 17.06 & 11.31 \\ 1.16 & -9.32\end{array}$




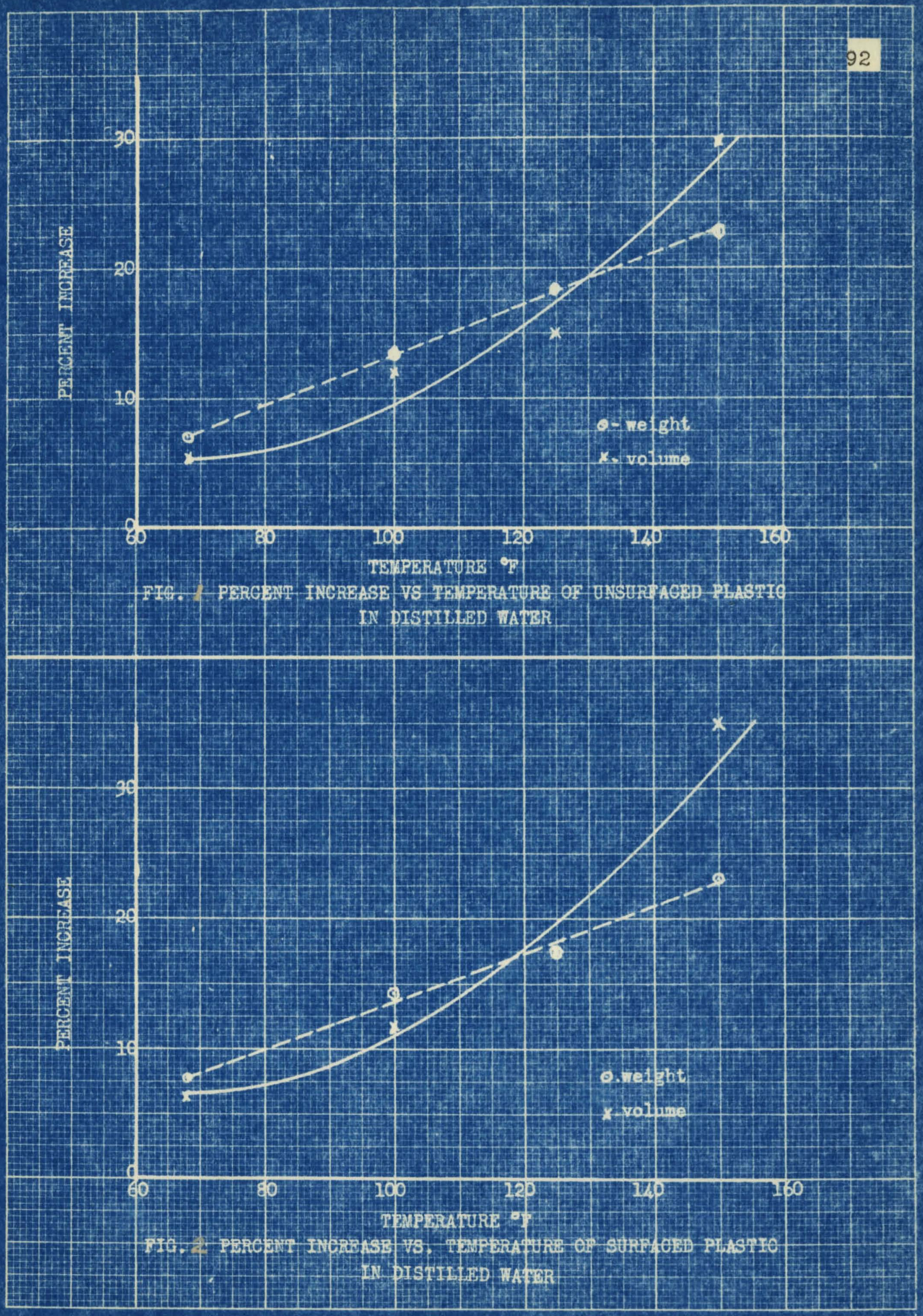




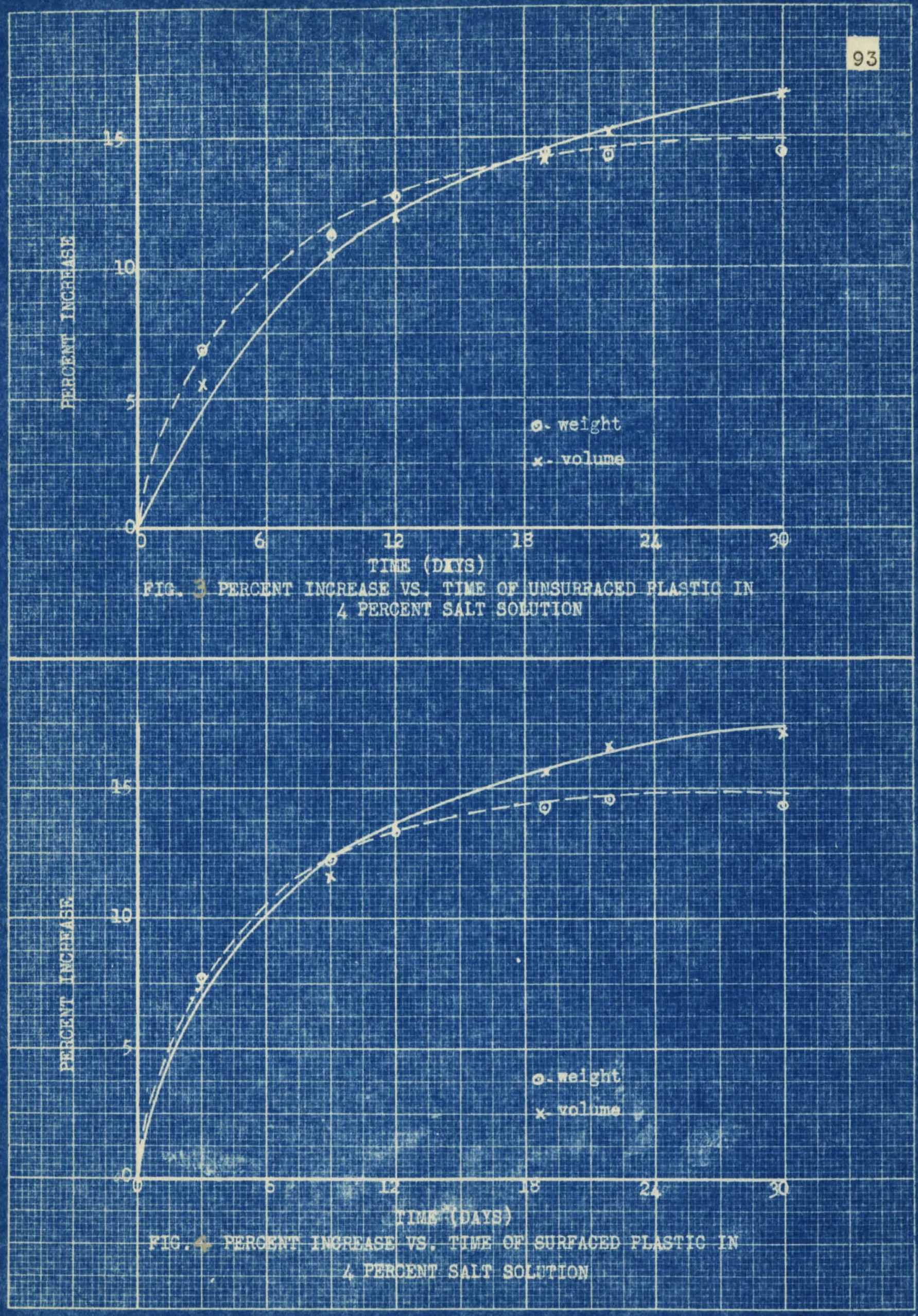


WESULS ARD ConoLustows 
Frow the dete provented in Tables I and II and from rigures 1 to 4 the following concluntons and results are arrived at.

Thto plastlo has no value whon oxpowed to water at elevated temperatures as it rapidy detoriontes. The onples were observed to brouk into sall pleoes at the tomperature of bolling water. At lower temperstures there wa a definite awelling of the plastic. The cogree of owelling Inoreased with Inareselns temporature of the water. The awelling was observed to be greatest in the direction of sompreastion.

The awelling is rapid at the beginning of 1morAon in sult water but later decreases. The waight Inerease tends to appronoh a constant value. Fros the dete it 1s soen that upon drying, the original volume is again closely attained. The dimenaion change of the samplea was noticeable, and a sifght owelling oan be dotocted. The wolght loss is considermble and indioates a solubility of the plastic. There 1s no appreciablo difference between the behavior of the ourfaced and unsurfaced axamples in of thor tost. 


\section{AchontwDatsws}

The anthor I whes to thank Gamble Bros., whoe division of Industrial Research Fallownip made this 1rvestifation possiblo. He niso wats to express his apprecintion to $z^{2}$. C. D. Dosker wo apervieed this problem and to hr. Charles Sacra who aslated in the experinental work. 


\section{vIra}

Jamea Irwin Stevens was born at Valloy station, Kentuaky, on July 15, 1920. He recelved his prisary and secondary duction in the public sobools of Jefferson County. He onterod the Speed Solentifte School of the University of Lowisville in September 1938 and obtalned the degree of Bachelor of Chemical Inglneering in Hay, 1942. Ho recelved the degree of Master of Chemical Enginooring in May, 1943.

Mr. Stevens was anarded the Federation of Paint and Varnish Production Men' Club Fellowahip as well as a D.I.R. Fellowahlp at the Univeralty of Loulsville for the yoar 1942-1943. Ipon completion of this work he wa employed by the Univerafty of Loulavilie as an Instructor In Chemical Engineering.

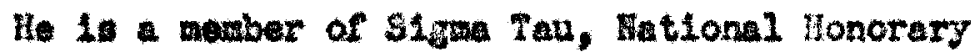
Ingineoring Fraternity, and of Theta Chi Delte, National Honorary Chemistry Pratornity. 